Studia Judaica 21 (2018), nr 2 (42), s. 373-404

doi:10.4467/24500100STJ.18.016.10267

Anna Rozenfeld

\title{
Audycje w języku jidysz w Polskim Radiu po II wojnie światowej
}

\author{
YIDDISH BROADCASTING ON THE POLISH RADIO AFTER WORLD WAR II
}

\begin{abstract}
The initiator of the establishment of Yiddish broadcasts in postwar Poland was Jonas Turkow. The first program in Yiddish was broadcasted by the Polish Radio (Polskie Radio) from the city of Lublin on January 6, 1945. For the first time in Poland's history Yiddish could be heard on the airwaves. It was also the first attempt to revive Yiddish and, most importantly, it came from a state institution before any Jewish organizations and institutions came to existence after World War II. After Jonas Turkow had left Poland, this activity was taken over by the Department of Culture and Propaganda in the Central Committee of Jews in Poland (CKŻP) in Warsaw. Between 1950 and 1958 the broadcasts were aired by the Jewish Section of the Polish Radio External Service and they could be heard only abroad. In January 1958, the Jewish Section of the Polish Radio was closed down by the decision of the Central Committee of the Polish United Workers' Party.
\end{abstract}

Keywords: Yiddish radio, Jonas Turkow, Yiddish language, Holocaust survivors, Polish Jews, Jews in Communist Poland.

Słowa kluczowe: radio jidysz, Jonas Turkow, język jidysz, ocaleni z Holokaustu, Żydzi polscy, Żydzi w komunistycznej Polsce. 
Nigdy nie zapomnę chwili, kiedy na falach eteru zabrzmiało w Lublinie pierwszy raz w historii Polski słowo żydowskie. To było wielkie przeżycie dla tych, którzy przekazywali wiadomości za granicę, jak i dla tych, którzy je odbierali.

Jonas Turkow, $1945^{1}$

\section{Wstęp}

Pierwsze nagranie rozpoczynające cykl regularnych audycji w języku jidysz zostało wyemitowane przez Polskie Radio z Lublina 6 stycznia 1945 r. ${ }^{2}$ Było to wydarzenie bez precedensu, gdyż wcześniej - w okresie przedwojennym - język ten pojawiał się na falach eteru jedynie sporadycznie ${ }^{3}$. Niniejszy artykuł został poświęcony audycjom w języku jidysz transmitowanym przez Polskie Radio począwszy od tego wydarzenia - które miało miejsce jeszcze przed wyzwoleniem Warszawy i pięć miesięcy przed oficjalnym zakończeniem II wojny światowej - aż do momentu zamknięcia redakcji żydowskiej w 1958 r. ${ }^{4}$ Jest on pierwszą próbą przybliżenia tej problematyki

1 „Ich wel kejnmol niszt fargesn dem moment, wen ojf di chwaljes fun eter hot zich derhert in Lublin dos erszte mol in der geszichte fun Pojln a jidisz wort. Dos iz gewen far di, welche hobn di jedijes kejn ojsland ibergegebn wi ojch far di, welche hobn di jedijes ojfgenumen - a grojse iberlebung". Zob. Jonas Turkow, Sprawozdanie z działalności Wydziału Kultury i Propagandy CKŻP, spisane w czerwcu 1945 r. w Warszawie [wynika to z treści tekstu], cz. III, s. 2. Oryginalny, dziewięciostronicowy maszynopis w języku jidysz, z naniesionymi ręcznie poprawkami, znajduje się w YIVO Archives, Territorial Collection, Poland III, sygn. RG116-Poland 3, folder 18. Jeżeli nie podano inaczej, wszystkie przekłady zostały dokonane przez autorkę artykułu.

${ }^{2}$ Rozmowy na temat powstania audycji rozpoczęły się jesienią 1944 r., a ostateczną decyzję w sprawie jej uruchomienia podjęto w grudniu 1944 r. Jewish Telegraphic Agency (JTA) podała 10 grudnia wiadomość, otrzymaną 8 grudnia z Moskwy, że wkrótce będzie transmitowany $\mathrm{z}$ radia $\mathrm{w}$ Lublinie program w języku jidysz. Mowa była o półgodzinnej audycji, która miałaby być nadawana codziennie. Zob. http://www.jta.org/1944/12/10/ archive/jews-flee-from-nazi-held-poland-to-liberated-area-communal-life-in-lublin-revives [dostęp: 1 stycznia 2017]. Pierwsza zapowiedź w języku jidysz pojawiła się na antenie Polskiego Radia 4 stycznia 1945 r.: „Hallo, hallo, do redt radjo-stacje Lublin! Onhojbndik fun szabes dem 6-tn januar weln ojf di chwaljes fun pojliszn radjo in Lublin ibergegebn wern ojdicjes in der jidiszer szprach”. (Hallo, hallo, tu mówi radiostacja Lublin! Począwszy od soboty 6 stycznia na falach Polskiego Radia w Lublinie nadawane będą audycje w języku żydowskim). Zob. transkrypt zapowiedzi audycji, Archiwum Żydowskiego Instytutu Historycznego [dalej: AŻIH], Wydział Kultury i Propagandy [dalej: WKiP], sygn. 303/XIII/71.

${ }^{3}$ Przed II wojną światową transmitowano pojedyncze utwory, piosenki w jidysz lub odczytywano fragmenty tekstów w tym języku.

${ }^{4}$ W dalszej części artykułu wspominam też krótko o audycjach Naje Chwaljes w języku jidysz nadawanych przez Polskie Radio dla Zagranicy w latach 2008-2012, lecz wzmianka ta ma tu charakter uboczny, temat ten bowiem będzie przedmiotem odrębnego opracowania. 
w ujęciu całościowym ${ }^{5}$. Podstawą analizy są wyniki badania źródeł, takich jak: dokumenty, nagrania i informacje rozproszone po archiwach i zbiorach prywatnych.

\section{Geneza audycji radiowych w języku jidysz}

Mimo trwających nadal działań wojennych II połowa 1944 r. przyniosła wydarzenia istotne dla odbudowy i nowej organizacji polskiej radiofonii. Grupa inicjatywna wywodząca się z Polskiego Komitetu Wyzwolenia Narodowego $(\mathrm{PKWN})^{6}$, z Wilhelmem Billigiem ${ }^{7}$ na czele, uruchomiła w sierpniu 1944 r. wagonową radiostację „Pszczółka”. Następnie 22 listopada tego samego roku utworzone zostało Przedsiębiorstwo Państwowe „Polskie Radio"8. Ulokowane w tymczasowej stolicy Polski, Lublinie, Polskie Radio

${ }^{5} \mathrm{~W}$ literaturze polskiej informacje na temat audycji w języku jidysz nadawanych przez Polskie Radio można znaleźć m.in. w: Nastęsstwa zagłady Żydów. Polska 1944-2010, red. Feliks Tych, Monika Adamczyk-Garbowska, Lublin 2011; Grzegorz Berendt, Życie żydowskie w Polsce w latach 1950-1956. Z dziejów Towarzystwa Społeczno-Kulturalnego Żydów w Polsce, Gdańsk 2008; Alina Cała, Mniejszość żydowska, [w:] Mniejszości narodowe w Polsce, red. Piotr Madajczyk, Warszawa 1998; Jerzy Myśliński, Mikrofon i polityka. Z dziejów radiofonii polskiej 1944-1960, Warszawa 1990. W literaturze anglojęzycznej wzmianki takie znajdują się w: Nathan Cohen, The Renewed Association of Yiddish Writers and Journalists in Poland, 1945-48, [w:] Yiddish after the Holocaust, red. Joseph Sherman, Oxford 2004. W języku jidysz oprócz Jonasa Turkowa (zob. Jonas Turkow, In kamf farn lebn, Buenos Aires 1949; tenże, Noch der bafrajung: zichrojnes, Buenos Aires 1959) o istnieniu audycji wspomina też Nachman Blumental (zob. Nachman Blumental, Lublin noch der cwejter welt-milchome, [w:] Dos Buch fun Lublin, Paris 1952, s. 593-598).

${ }_{6}$ W skład grupy oprócz Wilhelma Billiga wchodzili m.in.: Stanisław Nadzin, Zbigniew Lipiński, Henryk Lukrec, Wilhelmina Matuszewska, Jan Mietkowski, Jan Stefczyk. Więcej na ten temat zob.: Myśliński, Mikrofon i polityka..., s. 20; tenże, Radiofonia polska w latach 1944-1949, „Kwartalnik Historii Prasy Polskiej” 28 (1989), nr 3, s. 81-96; tenże, Kadra kierownicza Polskiego Radia w latach 1944-1960, „Kwartalnik Historii Prasy Polskiej” 30 (1991), nr 1, s. 71-77.

${ }^{7}$ Wilhelm Billig (1906-1985), ps. Wacław Bielecki, z wykształcenia polonista; w latach 1941-1943 pracował w redakcji polskiej radia radzieckiego w Moskwie i Kujbyszewie; potem kierował radiem Związku Patriotów Polskich. 23 listopada 1944 r. został mianowany dyrektorem Polskiego Radia i pozostał na tym stanowisku do roku 1951. Od listopada 1945 r. brał udział w pracach Wydziału Propagandy i Agitacji KC PPR i reprezentował Polskie Radio podczas spotkań pracowników Wydziału i szefów instytucji propagandowych. Por. Myśliński, Mikrofon i polityka..., s. 111; zob. także Wojciech Kalicki, Aparat propagandowy PPR (1944-1948), „Z Pola Walki” (1987), nr 1, s. 88-94. Następnie Wilhelm Billig był wiceministrem poczt i telegrafów (1951-1955) oraz łączności (1955-1956), w latach 1956-1968 zaś Pełnomocnikiem Rządu ds. Wykorzystania Energii Jądrowej. Informacje za: Myśliński, Mikrofon i polityka..., s. 114, oraz tenże, Radiofonia polska..., s. 84-85.

8 Więcej na ten temat zob. np.: Jerzy Myśliński, Odbudowa, zmagania dyrektora Wilhelma Billiga, [w:] tenże, Mikrofon i polityka..., s. 17-133; zob. także: Powojenne Polskie Radio $i$ jego szef, wywiad z Wilhelmem Billigem z 8 lipca 1979 r. w audycji radiowej, http:// 
nadawało audycje w językach: polskim, rosyjskim, francuskim i angielskim. Ukierunkowanie emisji audycji głównie na zagranicę wynikało przede wszystkim z ograniczonej liczby radioodbiorników w domach w Polsce, a także z motywów propagandowych. Audycje nadawane były na falach krótkich i transmitowane przez Moskwę 9

Powstanie audycji radiowych w języku jidysz związane jest nierozłącznie z osobą Jonasa Turkowa. On i jego żona Diana Blumenfeld byli żydowskimi aktorami, którzy przed wojną zajmowali prominentną pozycję w świecie teatru jidysz. W getcie warszawskim kontynuowali swoją aktywność teatralną, działając jednocześnie w ruchu oporu. Diana Blumenfeld zasłynęła jako śpiewaczka pieśni jidysz. Jako jedyni aktorzy przeżyli getto warszawskie ${ }^{10}$, z którego udało im się uciec i przedostać na aryjską stronę, gdzie ukrywali się pod zmienionymi nazwiskami, udając chrześcijan. Do wyzwolonego Lublina przybyli pod koniec września 1944 r. Turkow rzucił się tu w wir pracy na rzecz pomocy dla ocalałych Żydów ${ }^{11}$, angażując się w działalność Centralnego Komitetu Żydów w Polsce (CKŻP) ${ }^{12}$, założenie

www.polskieradio.pl/9/310/Artykul/276241,Powojenne-Polskie-Radio-i-jego-szef [dostęp: 1 stycznia 2017].

${ }_{9}$ Szerzej o powojennej historii radiofonii w Lublinie zob. np.: Stanisław Fornal, Anteny nad Bystrzyca, Lublin 1997.

${ }_{10}$ Diana Blumenfeld i Jonas Turkow często podkreślali fakt, iż byli ,,jedynymi aktorami, którzy przeżyli getto warszawskie”. Por. np. list Diany Blumenfeld do dyrektora WCBSTV, Ghetto Fighters' House Archives, Jonas Turkow Collection, sygn. 21414. Świadczą o tym również liczne artykuły w prasie, które ukazywały się po II wojnie światowej. Por. np. Chaim Ehrenreich, Di ejncike cwej aktjorn wos hobn zich geratewet fun der warszewer geto, „Forwerts” 54 (12 listopada 1950).

${ }^{11}$ Turkow pisze, że było to dla niego pewnego rodzaju antidotum na sytuację i stan psychiczny, w jakich się znajdował po ciężkich doświadczeniach wojennych. Nieustająca aktywność i zaangażowanie w pracę oraz pomoc innym pozwalała zapomnieć o własnym bólu i smutku (w tym okresie Turkow i jego żona Diana Blumenfeld byli oddzieleni od swojej jedynej córeczki, nie znając jej losów). Por. Turkow, In kamf..., s. 397-398.

${ }_{12}$ Centralny Komitet Żydów w Polsce (jid. Centraler Komitet fun di Jidn in Pojln), działający w latach 1944-1950, został powołany 12 listopada 1944 r. w celu reprezentowania Żydów wobec władz państwowych oraz zorganizowania opieki i pomocy Żydom ocalałym z Zagłady w Polsce. Wcześniej, tzn. od października do listopada 1944 r., działał Tymczasowy Centralny Komitet Żydów w Polsce. Do lutego 1945 r. CKŻP miał swoją siedzibę w Lublinie, następnie - do 1950 r. - w Warszawie. Funkcję przewodniczącego CKŻP sprawował początkowo Emil Sommerstein, a od 1946 r. - Adolf Berman. W 1949 r. przewodniczącym CKŻP został Hersz (Grzegorz) Smolar. Więcej na temat działalności CKŻP zob. np.: August Grabski, Centralny Komitet Żydów w Polsce (1944-1950). Historia polityczna, Warszawa 2015. Por. także: Alina Cała, Hanna Węgrzynek, Gabriela Zalewska, Historia i kultura Żydów polskich. Stownik, Warszawa 2000; Zarys dziatalności Centralnego Komitetu Żydów w Polsce za okres od 1 stycznia do 30 czerwca 1946, Warszawa 1947 / Tetikajts-baricht fun Central-komitet fun di Jidn in Pojln fun 1 januar 1946 biz dem 30 juni 1946, Warsze 1946. 
Związku Literatów, Dziennikarzy i Artystów Żydowskich ${ }^{13}$, wznowienie w Polsce działalności Żydowskiej Agencji Telegraficznej (ŻAT) ${ }^{14}$, a później - wydawanie „Biuletynu Żydowskiej Agencji Prasowej” („Biuletynu ŻAP" $)^{15}$. Jednak szczególną jego zasługą, a jednocześnie wyjątkowym wydarzeniem w historii Żydów polskich, było wprowadzenie przezeń żydowskich audycji radiowych do odbudowującego się wówczas Polskiego Radia $^{16}$.

Jako przewodniczący Związku Literatów, Dziennikarzy i Artystów Żydowskich Jonas Turkow postulował w liście do przewodniczącego PKWN Edwarda Osóbki-Morawskiego ${ }^{17}$ zorganizowanie audycji radiowych jednego z istotnych działań ${ }^{18}$ mających na celu odbudowę żydowskiego życia kulturalnego w Polsce. Powoływał się przy tym na zawartą w Manifeście $P K W N$ „możność swobodnego wyżycia się kulturalnego mniejszości

${ }_{13}$ Związek Literatów, Dziennikarzy i Artystów Żydowskich w Polsce (jid. Farejn fun Jidisze Literatn, Żurnalistn un Artistn in Pojln) był jedną z pierwszych instytucji żydowskich powstałych w wyzwolonym Lublinie w 1944 r. Przewodniczącym został Jonas Turkow. Więcej na temat powstania i działalności tego Związku zob. Cohen, The Renewed Association..., s. $15-36$.

14 Żydowska Agencja Telegraficzna - ŻAT (jid. Jidisze Telegrafen Agentur, ang. Jewish Telegraphic Agency - JTA), to agencja o międzynarodowym zasięgu, zajmująca się zbieraniem i rozpowszechnianiem wiadomości na temat wszelkich aspektów życia Żydów na świecie. Założona w 1917 r. przez Jakuba Landaua w Holandii, przed II wojną światową miała swe oddziały w Nowym Jorku, Londynie, Paryżu, Berlinie, Jerozolimie i Warszawie. Pod koniec 1944 r. ŻAT wznowiła działalność w Polsce, najpierw w Lublinie, a następnie w Łodzi - jako Żydowska Agencja Prasowa (ŻAP). Działała do 1950 r. i wydawała własne biuletyny ŻAP. Zob. Natalia Aleksiun, Żydowska Agencja Telegraficzna (்̇AT), [w:] Polski stownik judaistyczny, http://www.jhi.pl/psj/Zydowska_Agencja_Telegraficzna_(ZAT) [dostęp: 1 stycznia 2017].

${ }_{15}$ W „Biuletynie Żydowskiej Agencji Prasowej” z 13 listopada 1944 r. została podana następująca informacja: „LUBLIN (ŻAP). Niedobitki żydowskich dziennikarzy, pisarzy, artystów - drobne resztki rozgromionych przez hitleryzm wielkich rzesz pracowników kultury żydowskiej w Polsce - przystąpiły do pracy. W Lublinie zawiązał się Komitet Organizacyjny Związku Żydowskich Dziennikarzy, Pisarzy i Artystów, którego przewodniczącym został obrany Jonas Turkow, a sekretarzem Ozjasz Szlajen. Związek postawił sobie za zadanie zorganizowanie - wespół z Centralnym Komitetem Żydów Polskich - Informacyjnej Agencji Prasowej, założenie wydawnictwa, utworzenie komisji historycznej dla pełnego zbadania zbrodni niemieckich dokonanych na narodzie żydowskim oraz urządzenie audycji radiowych dla kraju i zagranicy”. „Biuletyn ŻAP” (13 listopada 1944), nr 1, k. 2.

16 Turkow, In kamf..., s. 397-398.

${ }^{17}$ List z 29 października 1944 r. do przewodniczącego PKWN Edwarda Osóbki-Morawskiego w sprawie rekonstrukcji żydowskiego życia kulturalnego, Lublin 1944. AŻIH, Spuścizna Jonasa Turkowa, sygn. S/364/4a.

${ }_{18} \mathrm{~W}$ liście tym oprócz zorganizowania audycji radiowych zostają wymienione również następujące działania mające na celu rekonstrukcję żydowskiego życia kulturalnego: zorganizowanie a) wydawnictwa żydowskiego, b) komisji historycznej, c) agencji prasowej. Tamże. 
narodowych”, widząc w tej nowej instytucji „orędownika demokracji i sprawiedliwości społecznej, walczącego o wskrzeszenie niepodległej, demokratycznej Polski"19.

Swój pomysł uruchomienia audycji w języku żydowskim Jonas Turkow postanowił przedstawić ówczesnemu dyrektorowi Polskiego Radia, Wilhelmowi Billigowi. By przekonać go do potrzeby stworzenia audycji a jidisze radjo-szo (radiowej godziny w języku żydowskim), używał różnych argumentów - wskazując zarówno na aspekt wizerunkowy, jak i humanitarny ${ }^{20}$. Według niego audycje te miałyby mieć zatem podwójne znaczenie. Po pierwsze - humanitarne, gdyż stanowiłyby konkretną pomoc w kontakcie ocalałych, którzy przeżyli w Polsce, z krewnymi i znajomymi za granicą. Po drugie - propagandowe, ponieważ ich emisja pokazałaby, że nowy polski rząd po raz pierwszy daje mniejszości żydowskiej możliwość nadawania audycji radiowych w swoim języku, co wcześniej nie było możliwe.

Dyrektor Billig, który znał się z Turkowem jeszcze sprzed wojny, po kilku dniach namysłu odpowiedział, że nie ma nic przeciwko audycjom w języku jidysz i pomysł mu się całkiem podoba, ale inne osoby z Zarządu mają odmienne zdanie. Niektóre z nich miały twierdzić, że stworzenie takiego programu może zostać źle odebrane przez Polaków, ponoć już twierdzących, iż Żydzi „zażydzili” Polskę (az Jidn hobn „farjidiszt” Pojln) ${ }^{21}$.

Turkow postanowił spotkać się z tymi, którzy byli przeciwnikami audycji, by spróbować ich przekonać do swego pomysłu. W spisanych w jidysz wspomnieniach ${ }^{22}$ relacjonuje ze szczegółami prowadzone wówczas rozmowy i przytaczane argumenty, które warto tu przypomnieć. Doszło zatem do spotkania stron - w gabinecie dyrektora Billiga zasiadła cała komisja, która miała podjąć ostateczną decyzję w tej sprawie. W spotkaniu wzięli udział:

1) Stefan Matuszewski - minister propagandy i informacji, były ksiądz, który jeszcze przed wojną został wykluczony z Kościoła katolickiego ze względu na komunistyczne przekonania;

2) zastępca Matuszewskiego - Stefan Wierbłowski, późniejszy ambasador w Czechosłowacji;

3) Jan Karol Wende - wiceminister kultury i sztuki, późniejszy ambasador w Jugosławii;

19 Tamże.

${ }^{20}$ Okoliczności powstania programu w języku jidysz opisuje Jonas Turkow w swojej książce - zob. Turkow, Noch der bafrajung...

21 Tamże, s. 35.

${ }^{22}$ Tamże, s. 35-38. 
4) pułkownik Wiktor Grosz ${ }^{23}$ - późniejszy generał, szef edukacji politycznej w armii polskiej;

5) dyrektor Polskiego Radia - Wilhelm Billig;

6) zastępca Billiga, dyrektor programowy Polskiego Radia - kapitan Stanisław Nadzin ${ }^{24}$.

Turkow przedstawił plan stworzenia i prowadzenia audycji w jidysz. Największym przeciwnikiem tego pomysłu okazał się Nadzin, który był zdania, że może to mieć szkodliwe skutki w aktualnej sytuacji w Polsce. Zamiast bowiem uspokoić Polaków, których nastawienie do Żydów nie jest pozytywne, może ich to zirytować, co pogorszy sytuację. Według niego należało ich najpierw przygotować do myśli, że Żydzi - tak samo jak inni obywatele kraju - mają prawo do wypowiadania się w swoim języku. Służyć temu celowi miałaby systematyczna propaganda.

Wende był tego samego zdania co Nadzin, uważał jednak, że powinno się pozwolić na specjalną audycję dla Żydów, która miałaby być jednak nadawana po polsku. Wierbłowski wyraził swoją opinię, iż „żargon”, który słyszalny byłby przez radio, w obecnej chwili nie poprawi antyżydowskiej atmosfery. Decyzja o uruchomieniu audycji dla Żydów mogła według niego mieć poważne następstwa, dlatego lepiej zaniechać realizacji tego pomysłu. Matuszewski, były ksiądz, uważał, że nie należy się kierować nastrojami „chuliganów” - powinni bowiem być stale zwalczani mocną ręką, więc i w tym przypadku nie można okazywać słabości. Należy wręcz podkreślać, że garstka ocalałych Żydów ma wsparcie i pomoc w każdym zakresie, aby się w nowej Polsce realizować kulturalnie i językowo. Udostępniając im państwowe radio, władze dowiodą swojej tolerancyjności i potwierdzą równouprawnienie wszystkich obywateli - bez względu na ich wyznanie. Wiktor Grosz zdecydowanie poparł Matuszewskiego. Podkreślił przy tym, iż „śmiesznie by wyglądała audycja żydowska po polsku, jak zaproponował Wende"25.

W czasie dyskusji padały argumenty za i przeciw. Sam Turkow, upominając się o prawo głosu, przekonywał $\mathrm{z}$ wielką determinacją, powołując się na Manifest $P K W N$, a nawet uciekając się do „wycieczek osobistych”:

${ }^{23}$ Wiktor Grosz, właśc. Izaak (Icchok) Medres.

${ }^{24}$ Stanisław Nadzin (właśc. Stanisław Guman) przed wojną pracował jako aktor w Jung Teater (Teatr Młodych) w Warszawie. Był Żydem, który przybył do Lublina z wojskiem polskim i pracował w radiu pod zmienionym nazwiskiem; nie był zresztą odosobniony - w Polskim Radiu pod zmienionymi nazwiskami pracowało wielu Żydów.

25 Turkow, Noch der bafrajung..., s. 37. 
Świat dowiedział się już o eksterminacji prawie całego żydostwa w Polsce. Niecierpliwie czeka na każdą wiadomość stąd. A świat żydowski jeszcze bardziej. Czy nie chcecie dać mu możliwości usłyszenia bezpośrednio od poszkodowanych, co Niemcy zrobili? A ci, co przeżyli - jak się z tego piekła uratowali? Czy nie uważacie, że taki bezpośredni kontakt więcej zdziała w propagandzie antyfaszystowskiej? W pewnych kręgach za granicą usiłuje się umniejszyć te straszliwe zbrodnie i przestępstwa, których dokonali niemieccy oprawcy w Polsce. Chce się zaciemnić koszmarny obraz okrutnej, brutalnej i wyrafinowanej eksterminacji polskiego żydostwa. Natomiast taki bezpośredni kontakt - jaki właśnie proponuję - tych, co najbardziej ucierpieli, ze światem zewnętrznym, wzbudzi też sympatię świata dla nowego polskiego rządu, który jako pierwszy umożliwił m.in. nadawanie w jidysz w radiu państwowym. To zawarte jest również w manifeście Tymczasowego Rządu Polskiego [... ${ }^{26}$ Nie zgadzam się z wypowiedziami moich przedmówców, że brzmienie języka żydowskiego jeszcze bardziej rozzłości polskich słuchaczy radia. Jeżeli chodzi o chuliganów - to raczej powinno się strzec przed pokazywaniem na ulicy żydowskich nosów, które denerwują ich tak czy tak, niezależnie od tego, czy właściciele tych nosów będą mówić po polsku, czy po żydowsku i czy będą się ukrywać pod zmienionymi, polskobrzmiącymi nazwiskami ${ }^{27}$.

W sytuacji podzielonych zdań, przedłużającej się dyskusji i niemożności podjęcia decyzji w sprawie audycji postanowiono porozumieć się z najważniejszym decydentem - Jakubem Bermanem ${ }^{28}$. Teraz wszystko zależało od niego. Jak dalej wspomina Turkow, po upływie tygodnia dyrektor Billig wezwał go ponownie do siebie, by oznajmić mu, że został mianowany kierownikiem odpowiedzialnym za prowadzenie audycji w języku żydowskim. Audycja wedle pierwszych postanowień miała odbywać się dwa razy w tygodniu po piętnaście minut. Centralną rolę miał odgrywać w niej Zuch-winkl fun krojwim (Kącik poszukiwania krewnych) ${ }^{29}$.

${ }^{26}$ Turkow powołuje się tutaj na następujące sformułowanie w Manifeście PKWN: „Żydom po bestialsku tępionym przez okupanta zapewniona zostanie odbudowa ich egzystencji oraz prawne i faktyczne równouprawnienie". Por. Manifest PKWN, Dziennik Ustaw z 1944 r., nr 1.

27 Turkow, Noch der bafrajung..., s. 37-38. Ostatnie cytowane zdanie to ironia i oczywista aluzja skierowana do członków Zarządu, którzy ukrywając swoje pochodzenie i działając pod zmienionymi nazwiskami, pośrednio zgadzali się na antysemityzm.

28 Jakub Berman (1901-1984) był członkiem Biura Politycznego Polskiej Partii Robotniczej (PPR) od sierpnia 1944 r. do grudnia 1948 r. W okresie od 1 stycznia do 30 listopada 1945 r. pełnił funkcję drugiego wiceministra spraw zagranicznych, a w latach 1954-1956 wiceprezesa Rady Ministrów. Zob. Anna Sobór-Świderska, Jakub Berman. Biografia komunisty, Warszawa 2009; Andrzej Tłomacki, Powrót do Polski w latach 1945-1948 pótnocnych rejonów Spiszu. Przyczynek do dziejów sporów granicznych między Polakami, Czechami i Stowakami, „Bezpieczeństwo. Teoria i Praktyka” (2011), nr 1, s. 100.

29 Turkow, Noch der bafrajung..., s. 38-39. 
W efekcie Jonas Turkow został oficjalnie pracownikiem Polskiego Radia $^{30}$, a audycje w języku jidysz zaczęto nadawać z Lublina w styczniu 1945 r. Audycje te były transmitowane w imieniu Związku Literatów, Dziennikarzy i Artystów Żydowskich oraz CKŻP trzy razy tygodniowo (w każdy wtorek, czwartek i w sobotę) na falach krótkich i średnich Polskiego Radia. W pierwszej audycji, wyemitowanej 6 stycznia 1945 r., w Polskim Radiu zabrzmiały następujące słowa w jidysz:

Hallo, hallo, do redt Lublin. Ojdicje fun Central-komitet fun Jidn in Pojln un Farejn fun Jidisze Literatn, Żurnalistn un Artistn in Pojln. Ojf di chwaljes fun pojliszn radjo 49,06 meter un 421 meter.

Brider Jidn fun ale ekn welt hert undzer sztim! Mir, di klejne col bajm lebn-geblibene Jidn ojf di bafrajte gebitn fun Pojln, szikn ajch iber undzer harcikstn jidiszn grus, mir lebn un weln lebn! [...]

Fun hajnt on wet ir hobn a gelegenhajt cu hern undzer wort. Ir wet hern di sztim fun di tchies-hamejsem ojfgesztanene, dos wort fun undzere gezelszaftleche aksonim un kultur-tuer. [...]

In di ramen fun undzere radjo-ojdicjes firn mir ojch ajn a kestl far zuchn krojwim in ojsland ${ }^{31}$.

W ten sposób dzięki determinacji i osobistemu zaangażowaniu jednej osoby stworzona została możliwość wykorzystania radia do zainicjowania procesu odbudowy życia żydowskiego po Zagładzie.

\section{Okres lubelski: w wirze walki politycznej}

Jonas Turkow zaczął przygotowywać i prowadzić audycje w jidysz, zabierając od czasu do czasu głos na antenie radia. Jako spikerka głównie występowała jego żona. „Kącik poszukiwań” cieszył się ogromnym powodzeniem.

${ }^{30}$ Por. zaświadczenie o zatrudnieniu Jana Tatarkiewicza-Turkowa (Jan Tatarkiewicz takim imieniem i nazwiskiem posługiwał się Turkow podczas wojny) w Polskim Radiu, wydane 13 stycznia 1945 r. przez Sekretariat PR w Lublinie. Zaświadczenie znajduje się w dokumentach osobistych Jonasa Turkowa w Archiwum ŻIH-u. AŻIH, Spuścizna Jonasa Turkowa, sygn. S/364/1a.

31 „Hallo, hallo, tu mówi Lublin. Audycja Centralnego Komitetu Żydów w Polsce i Związku Literatów, Dziennikarzy i Artystów Żydowskich w Polsce. Na falach Polskiego Radia 49,06 metra i 421 metrów. Bracia Żydzi z wszystkich zakątków świata, słuchajcie naszego głosu! My - mała garstka Żydów, którzy przeżyliśmy na wyzwolonych terenach Polski, przesyłamy Wam nasze najserdeczniejsze żydowskie pozdrowienia, żyjemy i będziemy żyć! [...] Od dzisiaj będziecie mieć możliwość słuchania naszego słowa. Usłyszycie głos powstałych-z-martwych, słowa naszych społecznych działaczy i aktywistów kulturalnych. [...] $\mathrm{W}$ ramach naszych audycji radiowych wprowadzamy również skrzynkę poszukiwań rodzin za granicą”. Zob. fragment transkryptu pierwszej audycji w języku jidysz, nadanej 6 stycznia 1945 r. z Lublina. AŻIH, WKiP, sygn. 303/XIII/71. 
Wkrótce po uruchomieniu audycji zaczęły przychodzić telegramy z różnych zakątków świata - pierwsze były z Palestyny z nazwiskami i zapytaniami o bliskich, czy żyją. Telegramy te nie szły bezpośrednio, lecz przez Moskwę. Przychodziły także listy z kraju, w których pozdrawiano krewnych i przyjaciół za granicą. W teczkach dokumentacji Wydziału Kultury i Propagandy, które znajdują się w Archiwum ŻIH-u, można z tego okresu znaleźć wypisane na karteczkach, przysyłane z całej Polski pozdrowienia dla rodzin: „Żyjemy, jesteśmy zdrowi, pozdrawiamy”32.

Turkow pisze, że dopiero po latach, kiedy już mieszkał za granica, zdał sobie sprawę, jak duże znaczenie miały te emitowane przez radio ogłoszenia, ilu ludzi dzięki nim się odnalazło lub uzyskało wiadomości o losach swoich bliskich. Ponadto dzięki tym audycjom setki, a potem tysiące ludzi z Palestyny, Londynu, Paryża i wszystkich innych miast europejskich dowiedziały się o ocalałych Żydach. Szczególne znaczenie miały one dla osób przebywających w obozach $\mathrm{DP}^{33}$. Wyłuskiwano z tych audycji nazwiska i adresy ocalałych osób i podawano je w prasie obozowej. Turkow opowiada, jak jego przyjaciel, Naftuli Zilberberg, przebywający akurat w obozie DP, usłyszał jego głos przez radio. Niezmiernie się wzruszył, bo był przekonany, że Turkow zginął. Napisał do niego pod adresem redakcji, prosząc, żeby za pomocą umówionego znaku przekazał mu informację, czy w danej sytuacji ma wracać do Polski. Turkow poprzez ten umówiony znak odradził mu powrót, dzięki czemu Zilberberg pozostał za granicą i zamieszkał potem w Paryżu ${ }^{34}$.

Turkow wspomina, że do redakcji zwracali się nie tylko uratowani Żydzi, ale też np. rosyjscy oficerowie i żołnierze żydowskiego pochodzenia, którzy znaleźli się ze swoimi oddziałami w Polsce i po raz pierwszy od kilku lat mieli możliwość poinformowania swoich rozproszonych po świecie bliskich o tym, że żyją. Zdarzały się też historie tragikomiczne: przychodzili na przykład wysokiej rangi urzędnicy państwowi i oficerowie na wysokich stanowiskach z prośbą, żeby podać ich nazwiska przez radio. Wówczas

odpowiadaliśmy, że nasza audycja służy tylko Żydom i żeby udali się do „kącika poszukiwań” dla nie-Żydów. I wtedy okazywało się, że te osoby, które wszyscy

${ }^{32}$ Zob. tamże, sygn. 303/XIII/70.

33 Obozy DP (DP camps, skrót od ang. displaced personscamps, także DPs) - obozy dla osób przemieszczonych (tzw. dipisów) były organizowane przez aliantów i działały po II wojnie światowej głównie na terenie Niemiec, Austrii i Włoch. Więcej na ten temat zob. np. „Trotz alledem lebe ich”. Jüdisches Leben in den DP-Lager 1945-1956, http://www.yadvashem.org/yv/de/exhibitions/dp_camps/index.asp [dostęp: 1 stycznia 2017].

${ }^{34}$ Turkow, Noch der bafrajung..., s. 51. 
uważali za stuprocentowych chrześcijan, zdradzały nam swą tajemnicę, iż oni też są Żydami, po czym szeptali nam na ucho swoje prawdziwe żydowskie imiona i nazwiska $^{35}$.

W audycjach oprócz emitowania list $\mathrm{z}$ nazwiskami poszukiwanych i poszukujących Turkow informował o wychodzących ciągle na jaw zbrodniach i bestialskich czynach Niemców, mówił o obozach zagłady, przytaczał relacje świadków ${ }^{36}$. Ważnym problemem dla Turkowa było informowanie na falach eteru o przypadkach mordów na Żydach przez Polaków, które miały miejsce już po wyzwoleniu ${ }^{37}$.

Nie ma dnia, w którym by Centralny Komitet Żydów Polskich [pisownia oryginalna] nie otrzymywał raportów o dalszym mordowaniu Żydów przez elementy reakcyjne spod znaku AK, które postawiły sobie za zadanie wymordowanie pozostałych przy życiu Żydów. Ohydne te mordy, dokonane na niewinnych ludziach, wywołały w obozie polskiej demokracji odruch wielkiego oburzenia i gniewu. Niejednokrotnie Polacy przypłacają życiem chęć ratowania Żydów. Podajemy kilka dalszych faktów ohydnych mordów popełnionych na bezbronnej ludności żydowskiej ${ }^{38}$.

Z nadzieją na reakcję ze strony Żydów, obywateli polskich za granicą, Turkow wzywał ich przez radio do protestowania i jak najszybszej pomocy dla ocalałych z Zagłady, a znajdujących się nadal w zagrożeniu Żydów w Polsce. Dramatyczne słowa Turkowa, które dziś brzmią jak komunistyczna propaganda, są próbą szukania pomocy w ochronie życia u nowej władzy ludowej. W swoim zaangażowaniu Turkow włączył się w polityczną

35 Tamże, s. 39-40.

${ }^{36}$ Świadczą o tym zachowane notatki i transkrypty przygotowywanych do odczytu audycji (AŻIH, WKiP, sygn. 303/XIII/68-75) oraz treści spisywanych po odsłuchaniu nadanych audycji z okresu od 8 lutego 1945 do 5 lipca 1945 r. (YIVO Archives, sygn. RG116-Poland 3, folder 6).

${ }^{37}$ W Archiwum ŻIH-u w teczkach Wydziału Kultury i Propagandy można odnaleźć informacje, notatki i teksty, które przygotowywał Jonas Turkow. Zob. AŻIH, WKiP, sygn. 303/XIII/68-75.

${ }^{38}$ Fragment transkryptu audycji przygotowanej przez Jonasa Turkowa (brakuje dokładnej daty), AŻIH, WKiP, sygn. 303/XIII/75. Dokument w języku polskim, maszynopis. Warte uwagi są dodatkowe, zamieszczone tu odręczne adnotacje: 1) W prawym dolnym rogu: „na zagranicę w żyd[owskim] i obcych językach”; 2) W dalszej części tekstu wymienione są miejscowości, w których doszło do mordów w ostatnich dniach: Żurawiczki, Grodzisko, Sieniawka, Drohiczyn, Zaręby Kościelne, Siemiatycze, Śniadowo, Ostrowiec Stokrzyski, Ryki, Kisielew, Jarosław, Ćmielów, Skotnica, Tarnobrzeg, Irena, Boćki, Czyżów; nazwy te zostały przekreślone z adnotacją, żeby sformułowanie „w następujących miejscowościach” zastąpić wyrażeniem „w rozmaitych miejscowościach” - bez wymieniania poszczególnych nazw; 3) Późniejsza adnotacja, umieszczona na środku: „nie poszło”. 
walkę pomiędzy „siłami narodowo-reakcyjnymi” a obozem tzw. żydokomuny. Wyrazem tego był apel:

Wzywamy wszystkich Żydów - obywateli polskich za granicą - do protestowania przeciwko mordom inspirowanym przez polską reakcję i dokonywanym przez jej agentów w kraju. Wzywamy wszystkich Żydów, obywateli polskich za granicą, do zjednoczenia się wokół Rady Narodowej i Polskiego Komitetu Wyzwolenia Narodowego w Lublinie jako jedynej gwarancji dla wolnej, demokratycznej Polski. Wzywamy wszystkich naszych braci za granicą do wielkiej i jak najszybszej pomocy dla małej resztki pozostałych przy życiu Żydów w Polsce.

Zauważamy, że jesteśmy nadal w walce, w szeregach wznowionego Wojska Polskiego, po stronie polskiej demokracji, przeciwko hitlerowskiemu napastnikowi. Nie zejdziemy z pola walki aż do ostatecznego wytępienia hitleryzmu ${ }^{39}$.

Po nadaniu takich informacji podczas audycji Turkow zaczął dostawać groźby na piśmie, z czego wynikało, że również polscy „chuligani”, których obawiali się niektórzy członkowie Zarządu Radia, najwidoczniej się tymi audycjami interesowali. Im bardziej jednak wzrastała popularność audycji, im większy miały one rozgłos i wpływ, tym bardziej wzrastało zagrożenie, pojawiały się coraz to nowe groźby pod adresem redakcji i radia w ogóle. Na przykład: dyrekcja radia w Lublinie otrzymała list z groźbą, że jeśli natychmiast nie wstrzyma audycji w języku jidysz, to cały budynek radia ${ }^{40}$ zostanie wysadzony w powietrze. I rzeczywiście do takiego zdarzenia doszło - do budynku radia wrzucono bombę, ale na szczęście nie wybuchła i nikomu nic się nie stało. Natomiast listy z groźbami nie ustawały. Redaktorzy audycji bali się przychodzić do pracy bez obstawy wojskowej. Wszystkie programy emitowane dla zagranicy były nadawane w godzinach wieczornych i redaktorzy nigdy nie wracali o tej porze do domu na piechotę. Ze wspomnień Turkowa wynika, że przyjeżdżał po nich specjalny wojskowy dżip, który pod obstawą odwoził ich do domu. Cały czas towarzyszyła im atmosfera strachu. Turkow pisze również, że po jakimś czasie się zorientował, iż bez przerwy są odgórnie kontrolowani: „Zrozumiałem, iż jest tu oko, które pilnuje każdego kroku, i ucho - każdego słowa"41.

${ }^{39}$ Fragment transkryptu audycji przygotowanej przez Jonasa Turkowa (6 stycznia 1945 r.). Dokument w języku jidysz. AZZIH, WKiP, sygn. 303/XIII/71.

40 Siedziba Polskiego Radia mieściła się wówczas w budynku przy ul. Krakowskie Przedmieście 62 w Lublinie.

${ }^{41}$ Turkow, Noch der bafrajung..., s. 49. 


\section{Okres warszawski: zmagania z cenzurą}

Kiedy 28 lutego 1945 r. CKŻP przeniósł swoją siedzibę z Lublina do Warszawy, gdzie kontynuował działalność, do dopiero co wyzwolonej stolicy przeprowadził się także Turkow. Wkrótce został kierownikiem Wydziału Kultury i Propagandy CKŻP. W Lublinie została jeszcze jego żona Diana, żeby na bieżąco nadawać audycje. Centrala Polskiego Radia - podobnie jak wszystkie inne instytucje państwowe - też już przeniosła się do Warszawy, ale audycja nadal była transmitowana z Lublina. O okresie przejściowym, tzn. „Warsze-Lublin” (Warszawa-Lublin), świadczą zapowiedzi radiowe, w których mówiono: „Hallo, hallo, do radjo-stacje Warsze-Lublin. Ojdicje fun Central-Komitet fun Jidn in Pojln un Farejn fun Jidisze Literatn, Żurnalistn un Artistn in Pojln. Ojf di kurce chwaljes 49,06 meter un mitele chwaljes 421 meter. Di hajntike ojdicje iz gewidmet..." jidysz zaczęto transmitować z Warszawy w czerwcu 1945 r. Rozszerzono je o dodatkowe piętnaście minut, tzn. były nadawane cztery razy w tygodniu: w niedzielę, we wtorek, w czwartek i sobotę.

Turkow opisuje dwie sytuacje, w których doszło do mocnych reakcji związanych z audycją i nadanym przezeń programem, gdy przebywał już w Warszawie. Jedna historia łączy się z przemówieniem dr. Emila Sommersteina ${ }^{43}$ w Krajowej Radzie Narodowej z 11 maja 1945 r. ${ }^{44}$ Przewodniczący CKŻP ostro skrytykował rząd polski za zbyt słabe zwalczanie polskich „chuliganów” dokonujących mordów na garstce Żydów ocalałych z Zagłady. Przemówienie to spotkało się z bardzo burzliwymi reakcjami, a Turkow uznał za swój obowiązek odtworzenie go w audycji. Chciał je nadać przez radio z dwóch powodów. Po pierwsze, aby świat dowiedział się o prawdziwej sytuacji Żydów w Polsce i zaczął wywierać większy nacisk na polskie organy państwowe, żeby pomogły Żydom w emigracji - zgodnie z obietnicą, którą złożył premier polski i inne organy państwowe. Po drugie,

42 „Hallo, hallo, tu radiostacja Warszawa-Lublin. Audycja Centralnego Komitetu Żydów w Polsce i Związku Literatów, Dziennikarzy i Artystów Żydowskich w Polsce. Na falach krótkich Polskiego Radia 49,06 metra i falach średnich 421 metrów. Dzisiejsza audycja poświęcona jest...” Dokument w języku jidysz, zapowiedź jednej z audycji w kwietniu 1945 r. AŻIH, WKiP, sygn. 303/XIII/72.

${ }^{43}$ Emil Sommerstein (1883-1957) w latach 1944-1946 był przewodniczącym CKŻP. Zob. Szymon Rudnicki, Żydzi w parlamencie II Rzeczypospolitej, Warszawa 2004, s. 411-419.

${ }^{44}$ Tekst przemówienia Emila Sommersteina wygłoszonego w KRN 11 maja 1945 r. został opublikowany w „Biuletynie ŻAP” (12 maja 1945) i jest dostępny w: AŻIH, WKiP, sygn. 303/XIII/129. Por. także: Dzieje Żydów w Polsce, 1944-1968. Teksty źródłowe, oprac. Alina Cała, Helena Datner-Śpiewak, Warszawa 1997, s. 105-111. 
chodziło mu o ostrzeżenie Żydów za granicą, którzy zastanawiali się nad powrotem do kraju z nadzieją, że zbudują tu sobie nowe życie. Słowa Emila Sommersteina miały im uzmysłowić, jak naprawdę wygląda sytuacja Żydów w Polsce ${ }^{45}$. Na reakcję nie trzeba było długo czekać: Turkowa wezwano do Ministerstwa Spraw Zagranicznych, gdzie spotkał się z zarzutem, że transmitował za granicę przemówienie, które mogło zostać źle odebrane. Nakazano mu ustalać wcześniej z ministerstwem, co będzie emitować, a jednocześnie zakazano nadawać kontrowersyjne treści bez wcześniejszej konsultacji z tą instancją i bez jej zgody. Oznaczało to poddanie audycji cenzurze.

Druga historia, która miała dla Turkowa poważne konsekwencje, związana jest z zawierającym antysemickie treści przemówieniem ministra spraw wewnętrznych Władysława Kiernika ${ }^{46}$ wygłoszonym na zgromadzeniu ludowym (zebraniu rolników) w miasteczku pod Krakowem. Turkow chciał, żeby usłyszano za granicą, jaka jest sytuacja w Polsce i jakie poglądy wygłasza przedstawiciel rządu polskiego. Przygotował więc materiał dotyczący tego przemówienia oraz scenariusze paru kolejnych audycji, a sam wyjechał na ponadtygodniową podróż po Polsce. Według planu przemówienie miało zostać nadane w audycji niedzielnej. We wtorek Turkow chciał posłuchać audycji w radiu, ale ku jego zdumieniu - nie została ona nadana: zamiast piętnastominutowego programu w języku jidysz, który był zawsze emitowany zaraz po audycji francuskiej, tym razem puszczono muzykę. Pomyślał wtedy, że być może zachorowała spikerka... Postanowił więc posłuchać audycji w czwartek. Znowu jednak audycji nie nadano. Kiedy to samo powtórzyło się w sobotę i niedzielę, Turkow zrozumiał, że audycje wstrzymano. Po powrocie do Warszawy udał się natychmiast do dyrektora radia, Wilhelma Billiga, który powiedział mu, że wokół audycji w jidysz powstało spore zamieszanie i z Ministerstwa Spraw Zagranicznych przyszedł zakaz ich nadawania, ponieważ zawierały treści antypaństwowe. Billig poradził Turkowowi, aby złożył wizytę Jakubowi Bermanowi ${ }^{47}-$

${ }^{45}$ Relacja z audycji z przemówieniem Emila Sommersteina, nadanej przez Turkowa 13 maja 1945 r., została załączona w liście do Rady do spraw Ratowania Ludności Żydowskiej w Polsce, podpisanym: „w/z Dra Manfreda Lachsa L. Fremt”, Londyn, 15 maja 1945 r. Ghetto Fighters' House Archives, Anszel Reiss Collection, sygn. 28131.

${ }_{46}$ Władysław Kiernik (1879-1971), minister administracji publicznej od 28 czerwca 1945 r. do 5 lutego 1947 r. Zob. https://bs.sejm.gov.pl/F?func $=$ find-b\&request $=000000642$ \&find_code $=$ SYS\&local_base $=$ ARS10 [dostęp: 1 stycznia 2017].

${ }_{47}$ Zob. przyp. 28. 
zastępcy ministra Wincentego Rzymowskiego ${ }^{48}$. Ten jednak go nie przyjął, a rozmowę zlecił sekretarce, która - według relacji Turkowa - przywitała go w następujący sposób:

- Panie Turkow, nie jest dobrze. [...] Podczas pańskiej nieobecności spikerka pozwoliła sobie nadać audycję wyraźnie antypaństwową. Minister nakazał więc wstrzymać pańskie programy do czasu, aż pan wróci i wyjaśni tę sprawę.

- Czy mógłbym porozmawiać z ministrem Rzymowskim?

- To nie ma związku z Rzymowskim, tylko z Bermanem.

- Czy mógłbym porozmawiać z ministrem Bermanem?

- Minister jest dzisiaj bardzo zajęty konferencją...

- To porozmawiam z nim, jak będzie wolny.

- To niepotrzebne. [...] Minister kazał mi przekazać, że od dzisiaj, zanim pan nada program w radiu, musi pan dostarczyć cały tekst. Dopiero jak zostanie on zaakceptowany, będzie mógł pan go dać do emisji. Nie jest to działanie skierowane tylko przeciwko panu. Kierownicy innych redakcji zagranicznych robią tak od dawna. Dotychczas patrzyliśmy na pańskie audycje przez palce, ale to zdarza się już po raz drugi, że przekazuje pan za granicę rzeczy, których sobie nie życzymy, które nie są dobre dla naszej polityki zagranicznej.

- Zadam pani pytanie: Mówi pani, że nadaliśmy dwa programy, które są antypaństwowe. Pewnie pani ma na myśli przemówienie dr. Sommersteina, które wygłosił w sejmie, i ministra Kiernika, które wygłosił dla rolników. Myślałem, że przemówienie, które się wygłasza w parlamencie, mogę dokładnie tak, jak ukazało się w prasie, emitować w radio. Co do tego drugiego przemówienia - ministra administracji publicznej, dr. Władysława Kiernika, to zgadzam się z panią, że było ono antypaństwowe, bo Kiernik zaatakował w nim żydowską mniejszość narodową. Ale przemówienie to zostało wygłoszone przecież przez ministra polskiego rządu i jeśli on nie został za to ukarany, to dlaczego ja mam być ukarany za powtórzenie tylko treści jego przemówienia? Natomiast co do cenzury, którą zamierzacie wprowadzić dla audycji żydowskich, to ona mnie w sumie już nie interesuje, gdyż rezygnuję z mojego stanowiska. Jeszcze dzisiaj przekażę moją dymisję dyrektorowi Billigowi ${ }^{49}$.

Wkrótce po tym incydencie w ministerstwie Turkow wyjechał za granicę, opuszczając Polskę na zawsze. I tak zakończyło się prowadzenie przezeń audycji w języku jidysz. Od stycznia 1945 r. do późnej jesieni 1945 r. wyemitował - jak sam pisze - 158 audycji w tym języku ${ }^{50}$.

${ }^{48}$ Wincenty Rzymowski (1883-1950) pełnił funkcję ministra spraw zagranicznych oraz ministra kultury i sztuki w latach 1944-1947. Zob. Ludwik Hass, Rzymowski Wincenty, [w:] Polski Słownik Biograficzny, t. 34/2, z. 141, Wrocław 1992, s. 213-218; Lucyna Chmielewska, Wincenty Rzymowski (1883-1950). Publicysta i polityk, „Dzieje Najnowsze” 36 (2004), nr 2, s. $211-215$.

${ }^{49}$ Turkow, Noch der bafrajung..., s. 268-269.

50 Tamże, s. 51. 
Znaczenie radia w języku jidysz w tym okresie było szczególne. Przekazywanie bieżących informacji miało na celu nie tylko niesienie pomocy w odbudowie rodzin zdziesiątkowanych podczas wojny, ale przede wszystkim ponowne tworzenie społeczności żydowskiej w Polsce poprzez integrowanie ocalałych wokół nowo powstających instytucji kultury narodowej. Radio w języku jidysz było w tym czasie instytucją kultury o najszerszym zasięgu. Ponadto w powojennej chaotycznej i niepewnej rzeczywistości informacyjne audycje radiowe miały za zadanie porządkować wiedzę o realnej sytuacji bytowej i politycznej, pomagając jednocześnie w podejmowaniu indywidualnych decyzji co do miejsca odbudowy własnego życia osobom pozostającym poza krajem. Problemy związane z repatriacją zajmowały szczególnie ważne miejsce.

\section{Zmiany w audycjach w języku jidysz po 1945 roku}

Po wyjeździe Turkowa audycje w języku jidysz były kontynuowane. Władzom Polski Ludowej bardzo zależało na pokazaniu, że nie tolerują antysemityzmu i roztaczają opiekę nad ludnością żydowską ${ }^{51}$. O kontynuacji audycji świadczy dokumentacja działalności Wydziału Kultury i Propagandy CKŻP do 1950 r. znajdująca się w Archiwum ŻIH w Warszawie ${ }^{52}$ oraz dokumenty, transkrypty, zapisy audycji, protokoły, korespondencja, a także echa prasowe zgromadzone w archiwach i zbiorach prywatnych w Polsce i rozproszone po całym świecie.

Po odejściu Turkowa w audycjach żydowskich nastąpiły zmiany organizacyjne, techniczne i merytoryczne. Audycje były przygotowywane przez CKŻP w Wydziale Kultury i Propagandy. Referat radiowy stanowił jedną z najważniejszych komórek tego Wydziału, a jego głównym zadaniem było „krzewienie kultury narodowej wśród ludności żydowskiej i informowanie Żydów w kraju i za granicą o sytuacji politycznej, społecznej, ekonomicznej i kulturalnej Żydów w Polsce"53.

Istotną zmianą było zaprzestanie nadawania audycji w jidysz na falach średnich, co oznaczało, że przestały być one słyszalne w Polsce. Programy te były skierowane do Żydów za granicą - głównie w Stanach Zjednoczonych i Europie Zachodniej. O ile w zapowiedziach audycji przygotowywanych

${ }^{51}$ Por. Berendt, Życie żydowskie..., s. 56.

52 Są to transkrypty i plany audycji do roku 1950, notatki, materiał roboczy audycji, dokumenty i korespondencja przychodząca do Redakcji Audycji/Referatu Radiowego przy CKŻP.

${ }_{53}$ Zarys działalności..., s. 15. / Tetikajts-baricht..., s. 14. 
przez Turkowa podawano częstotliwości na falach krótkich $(49,06 \mathrm{~m})$ i średnich $(421 \mathrm{~m})^{54}$, o tyle po roku 1945 - już tylko na falach krótkich $(49,06 \mathrm{~m})^{55}$. Programy były nadawane cztery razy w tygodniu o godz. 22.10 czasu środkowoeuropejskiego, a ich propagandowy cel - obliczony na słuchacza zagranicznego - stawał się coraz wyraźniejszy:

W ramach tych audycji zagranica jest dokładnie informowana o wszystkich osiaggnięciach CKŻ w Polsce oraz o wszystkich przejawach związanych z życiem ludności żydowskiej w Polsce. [...] Z dziedziny życia politycznego w audycjach radiowych znajdują swe odbicie interwencje przedstawicieli społeczeństwa żydowskiego u władz państwowych, a także udział Żydów w życiu politycznym kraju ${ }^{56}$.

Ocieplaniu wizerunku miało służyć rozwijanie takich tematów, jak opieka nad dzieckiem czy kwestie społeczne związane z repatriacją ${ }^{57}$.

W Wydziale Kultury i Propagandy przygotowywano program audycji na piśmie w trzech egzemplarzach w języku jidysz, a w pięciu - po polsku, gdyż taki był wymóg Dyrekcji Programowej Polskiego Radia w Warszawie, o czym świadczy korespondencja między tą Dyrekcją a CKŻP ${ }^{58}$. Tekst musiał być sprawdzony i zaakceptowany do transmisji ${ }^{59}$ przez Dyrekcję Programową Wydziału Audycji Zagranicznych, Dyrekcję Polskiego Radia i Ministerstwo Spraw Zagranicznych. Dopiero po uzyskanej akceptacji tych instancji spikerka mogła odczytać w radiu przygotowany tekst. Ingerencje cenzury były coraz częstsze - w dokumentacji przygotowywanych tekstów audycji natrafia się na wykreślenia, uwagi („proszę usunąć”, „proszę zmienić”) albo adnotacje: „nie poszło”, „cenzura nie przepuściła” ${ }^{\circ}$.

${ }^{54}$ Por. zapowiedzi audycji: AŻIH, WKiP, sygn. 303/XIII/72.

${ }_{55}$ Zarys działalności..., s. 15. / Tetikajts-baricht..., s. 14.

56 Tamże.

57 Tamże.

58 Por. np.: 1) Pismo od Dyrektora Programowego Polskiego Radia w Warszawie do CKŻP z 13 listopada 1945 r., podpisane przez Kierownika Sekretariatu Dyrekcji Programowej PR - p. Jadwigę Rabęcką, o treści: „Prosimy o nadsyłanie audycji Żydowskich w 3-ch egzemplarzach" [pisownia oryginalna]. 2) Pismo z Wydziału Audycji Zagranicznych Polskiego Radia do Redakcji Audycji w Języku Żydowskim z 14 lutego 1946 r., podpisane przez Naczelnika Wydziału - p. Irenę Wróblewską, w którym zaznaczono: „Prosimy [...] o przysyłanie 3 egzemplarzy w języku żydowskim oraz 5-ciu egzemplarzy tłumaczenia”. AŻIH, WKiP, sygn. 303/XIII/68.

${ }_{59}$ Por. np. Pismo z Wydziału Audycji Zagranicznych Polskiego Radia do Redakcji Audycji w Języku Żydowskim z 14 lutego 1946 r., podpisane przez Naczelnika Wydziału Irenę Wróblewską: „komunikuję, że na przyszłość audycja, która nie przejdzie przez nasz wydział, nie będzie mogła być wygłoszona”. Tamże.

${ }^{60}$ Por. np. przygotowane teksty audycji: 1) z 10 lutego 1946 r. z adnotacją „nie nadano”; 2) z 2 marca 1946 r. z adnotacją ,cenzura nie przepuściła”; 3) z 19 marca 1946 r. z wykreśleniami. Tamże, sygn. 303/XIII/76. 
Wśród osób, które pracowały w tym okresie w oddziale radiowym CKŻP, napotykamy nazwiska Alicji Karcz (Alicji Karczowej) ${ }^{61}$ i Józefa Okrutnego ${ }^{62}$. Spikerkami audycji żydowskich w Polskim Radiu były Felicja Skwarska oraz Dorota Żelazo ${ }^{63}$. Od 21 lipca 1946 r. wprowadzono pewne novum: jedna audycja w tygodniu (w niedzielę) była artystyczno-literacka. W dokumencie z końca lipca 1946 r. pt. Audycje żydowskie w Polskim Radio czytamy: „Ostatnio wprowadzono pewną innowację w audycjach, a mianowicie jeden raz w tygodniu cała audycja jest poświęcona literaturze, pisarzom, teatrowi i aktorom żydowskim" ${ }^{64}$. Pierwsza audycja artystyczno-literacka odbyła się w niedzielę 21 lipca z udziałem aktorów byłego Teatru Młodych ${ }^{65}$ : Abrahama Wołowczyka i Josefa Heibluma, którzy recytowali wiersze: Nacht-wechter [Nocna warta] Icchoka Lejbusza Pereca, Wen ich wel kumen ahejm [Gdy wrócę do domu] Nachuma Bomzego, On Jidn [Bez Żydów] Binema Hellera i Di richter [Sędziowie] Lejba Morgentoja. W kolejnej audycji artystyczno-literackiej, która została nadana w dniu 28 lipca, aktorzy Josef Glikson i Cypora Fajnzylber recytowali wiersze: Chajima Nachmana Bialika Di szchite [Rzeź], Icchoka Perłowa Bedamajich chaj [W krwi twojej życie] oraz fragment poematu Binema Hellera Warsze 1939 [Warszawa 1939] ${ }^{66}$.

Audycje poświęcone zagadnieniom literatury i sztuki żydowskiej z udziałem literatów i artystów żydowskich były nadawane regularnie. Z archiwaliów dowiadujemy się m.in. o gościnnych występach Molly Picon i Jacoba Kalicha

${ }^{61}$ Alicja Karcz (Karczowa), redaktorka audycji i tłumaczka z polskiego na jidysz i z jidysz na polski, rozpoczęła pracę w oddziale radiowym CKŻP jesienią 1945 r. O swoich obowiązkach zawodowych pisze w liście 2 listopada 1945 r. do swoich krewnych w Ameryce. Oryginał listu w języku polskim znajduje się w Archiwum YIVO w Nowym Jorku. YIVO Archives, sygn. RG116-Poland 3, folder 186.

${ }^{62}$ Józef Okrutny (właśc. Jojsef Turko, 1906-1991), pisarz; urodził się w Kutnie, dzieciństwo spędził w Łodzi. II wojnę światową przeżył na terenie Związku Radzieckiego. Do Polski wrócił w 1946 r. i do września 1949 r. pracował jako redaktor audycji żydowskich w oddziale radiowym Wydziału Kultury i Propagandy CKŻP. Następnie wyjechał z Polski, przebywał w Austrii i we Włoszech, a w 1951 r. osiadł w Buenos Aires. Zob. Yoysef Okrutni (Iosef Okrutny), http://yleksikon.blogspot.de/2014/09/yoysef-okrutni-iosef-okrutny.html [dostęp: 1 stycznia 2017].

${ }^{63}$ Informacja za listem od Dyrekcji Polskiego Radia (podpisanym przez dyrektora Zygmunta Młynarskiego) do Referatu Radiowego przy CKŻP z 29 kwietnia 1947 r., dotyczącym spikerek audycji żydowskich. AŻIH, WKiP, sygn. 303/XIII/68.

${ }_{64}$ Dokument Audycje żydowskie w Polskim Radio z końca lipca 1946 r. (dokument istnieje oryginalnie w języku jidysz i w tłumaczeniu na język polski). Tamże, sygn. 303/XIII/70.

65 Teatr Młodych (jid. Jung Teater), awangardowy zespół żydowski działający w latach 1932-1937 w Warszawie, założony przez Michała Weicherta.

${ }^{66}$ Na podstawie dokumentu Audycje żydowskie w Polskim Radio z końca lipca 1946 r. Tamże. 
prezentujących swój repertuar pt. 500 lat teatru żydowskiego, o poetach Chaimie Grade i Awromie Suckewerze, którzy „odczytali swoje najnowsze utwory" ${ }^{67}$, o artystce teatru żydowskiego w Białymstoku Dorze Rubinie, która „śpiewała pieśni ghettowe, zebrane i opracowane przez nią podczas jej pobytu w ghetcie wileńskim" ${ }^{68}$.

Tematy poruszane $\mathrm{w}$ audycjach najlepiej można prześledzić na przykładzie zachowanego programu z jednego tygodnia, tj. czterech audycji od wtorku do niedzieli, 19-24 listopada 1946 r.:

19 listopada (wtorek)

Biuletyn Wydziału Młodzieżowego przy CKŻP

Oświadczenie Prezydenta Jointu Edwarda Warburga przed opuszczeniem Polski

Działalność Żydowskiego Towarzystwa Krzewienia Sztuk Pięknych w Polsce

Ziomkostwo wotyńskie uczciło pamięć zamordowanych Żydów

Z Dolnego Śląka

Uroczyste zamknięcie wystawy Mandelcwajga

21 listopada (czwartek)

Społeczeństwo żydowskie w Polsce na rzecz daniny narodowej

Delegacja CKŻP w CKW PPS

Odnalezienie nowego masowego grobu żydowskiego (w białostockiem)

Rozwój społeczności żydowskiej w Polsce

Żydowska spółdzielnia rybacka w Szczecinie

Powodzenie kompozycji muzyka Wajnera w Ameryce (po pobycie w Polsce Molly Picon i Jacoba Kalicha)

„Jak bida to do Żyda”-tekst C. Zatrejn

Ostatnie przygotowania do procesu Bibowa w Łodzi

Telegram Jointu do Centralnego Komitetu Żydów w Polsce

23 listopada (sobota)

Żydzi w Polsce przed wyborami (19 stycznia 1947)

Echa zajść kieleckich (o rozprawie / wspótwinni mordów przed sądem)

Udziat Żydów wakcji wyborczej

Otwarcie 9 skrzyni Archiwum Ringelbluma

Konferencja Kultury Żydowskiej na Dolnym Śląku

Proces Sąu Obywatelskiego przy CKŻP nad Szapsa Rotholcem (popularny bokser/ policjant $w$ ghetcie warszawskim)

24 listopada (niedziela) - audycja artystyczno-literacka

Elchanan Wogler [o poecie i prezentacja jego wierszy]

„Do lekarki w biatym fartuchu”

${ }^{67}$ Zob. „Biuletyn Wydziału Młodzieżowego Centralnego Komitetu Żydów Polskich” (1947), nr 4-5, s. 20.

68 Tamże. 
„Pozostatem jeden z tysiaca”

"Czerwone wrota”

„Pieśń czerwonoarmistów” ${ }^{69}$

Wszystkie teksty audycji znajdowały się pod kontrolą cenzury państwowej. W kolejnych latach program nabierał charakteru zdecydowanie propagandowego ${ }^{70}$. Czasem audycje były zarządzane odgórnie: wszystkie redakcje audycji zagranicznych otrzymywały od Redakcji Centralnej Polskiego Radia ten sam tekst do przetłumaczenia na dany język, np. Otwarcie kongresu PZPR. Przemowa Bolesława Bieruta (15 grudnia 1948 r. $)^{71}$.

Przyjąwszy założenie, iż audycje radiowe w języku żydowskim mają na celu „informowanie społeczeństwa żydowskiego o osiągnięciach Polski Ludowej oraz o życiu ludności żydowskiej w kraju we wszystkich dziedzinach" 72 , ustalono, że program audycji składać się będzie z bieżących wiadomości ogólnokrajowych i żydowskich:

Audycje mają być przeznaczone w pierwszym rzędzie dla Żydów z USA i krajów Europy Zachodniej, toteż program tych audycji przewiduje, oprócz wiadomości z Polski, wiadomości z życia innych krajów demokracji ludowej, a także naświetlenie sytuacji w Palestynie. Program również przewiduje audycje literackie, muzyczne i słowno-muzyczne oraz zapoznanie Żydów z osiągnięciami kultury postępowej na całym świecie, ze szczególnym uwzględnieniem rozwoju kulturalnego Polski Ludowej $^{73}$.

Trudno oszacować, jaka była słuchalność audycji żydowskich z tego okresu, ale niewątpliwie radio w języku jidysz było instytucją kultury o szerokim, międzynarodowym zasięgu. Z archiwalnej dokumentacji z 1949 r. wynika:

Według posiadanych informacji audycji żydowskich słuchają szczególnie w Londynie, Paryżu, Szwajcarii i Belgii. Biuletyn Europejskiego Biura Światowego Kongresu Żydowskiego w Londynie wykorzystuje wiadomości z naszych audycji. We Francji liczbę słuchaczy oceniamy na blisko 5000 osób. Z krajów demo-

${ }^{69}$ Zob. AŻIH, WKiP, sygn. 303/XIII/79.

${ }^{70}$ Por. plan audycji z 11 maja 1948 r.: „Premier Cyrankiewicz zwiedza międzynarodowe targi w Poznaniu / Zacieśnianie współpracy między SL a PRL-em / Reprezentacja Polski zajęła pierwsze miejsce w międzynarodowym biegu kolarskim Warszawa-Praga / Uroczyste wręczenie orderów i medali Żydom uczestnikom walk z faszyzmem / Narada TOZu w Łodzi / Obóz letni dla dzieci żydowskich”. Zob. tamże, sygn. 303/XIII/89.

71 Tamże, sygn. 303/XIII/96 (w jidysz); tamże, sygn. 303/XIII/98 (po polsku).

72 Tamże.

${ }^{73}$ Tamże. 
kracji ludowej naszymi audycjami interesują się w pierwszym rzędzie Rumunia i Czechosłowacja. Odgłosów ze Stanów Zjednoczonych nie posiadamy ${ }^{74}$.

Do $1950 \mathrm{r}$. audycje nadawano cztery razy w tygodniu. Od połowy lutego 1950 r. powiększono liczbę ich emisji do sześciu razy w tygodniu - codziennie oprócz środy. Zmieniono godzinę i częstotliwość fal ich nadawania, a także rozszerzono i wzbogacono program. O wprowadzonych zmianach poinformowano w audycji z 2 lutego $1950 \mathrm{r}$.:

Speaker (po zapowiedzi): Komunikujemy Wam ważną wiadomość. Począwszy od czwartku, 16 lutego, tzn. za dwa tygodnie, nadawać będziemy audycje radiowe w języku żydowskim codziennie oprócz środy.

Codziennie oprócz środy, na krótkich falach, 48,23 - powtarzam, na krótkich falach, 48,23, - o godz. 8-ej 15 wieczorem wg czasu środkowo-europejskiego usłyszycie o życiu polskich i żydowskich mas ludowych, kroczących ku nowemu, radosnemu życiu.

W naszych audycjach radiowych postaramy się odzwierciedlić wielki proces odbudowy ludowo-demokratycznej Polski, proces, do którego włączyły się także najszersze rzesze pracującej ludności żydowskiej. W naszych audycjach usłyszycie ostatnie i najważniejsze wiadomości z wszystkich dziedzin politycznego, gospodarczego i społecznego życia w kraju. Audycje literackie i muzyczno-wokalne zapoznają Was z najnowszymi, jako też klasycznymi utworami polskiej i żydowskiej kultury. Przeglądy prasy zapoznają Was z aktualną tematyką polskiej i żydowskiej działalności na polu publicystycznym. Celem nawiązania ściślejszego kontaktu z naszymi słuchaczami, bylibyśmy bardzo zadowoleni, gdybyśmy dostali od nich listy o naszych audycjach radiowych w języku żydowskim. Wszystkie uwagi, jak również życzenia prosimy nadsyłać pod adresem Centralnego Komitetu Żydów w Polsce, Warszawa - Sienna 60 dla Wydziału Kultury i Propagandy ${ }^{75}$.

\section{Działalność redakcji żydowskiej w latach 1950-1958}

29 października 1950 r. w wyniku połączenia CKŻP z Żydowskim Towarzystwem Kultury i Sztuki (ŻTKiS) powstało Towarzystwo Społeczno-Kulturalne Żydów w Polsce (TSKŻ). W miejsce dotychczasowego referatu radiowego Wydziału Kultury i Propagandy CKŻP powstała redakcja audycji w języku żydowskim przy Polskim Radiu. Należała ona do Działu Zachodnioeuropejskiego w Zespole Programu dla Zagranicy Polskiego Radia. TSKŻ pozostawało w stałym kontakcie z redakcją żydowską, a członkowie

\footnotetext{
${ }^{74}$ Informacja o audycjach radiowych $w$ języku żydowskim. Dokument w języku polskim z 30 września 1949 r. Tamże, sygn. 303/XIII/106.

${ }^{75}$ Informacja o zmianach w nadawaniu audycji żydowskiej z 2 lutego 1950 r. Tamże, sygn. 303/XIII/112.
} 
Towarzystwa współpracowali z nią, dostarczając odpowiednie materiały. Świadczą o tym m.in. protokoły z posiedzeń Prezydium TSK $\dot{Z}^{76}$ oraz zachowane dokumenty z działalności redakcji w latach pięćdziesiątych ${ }^{77}$. W redakcji żydowskiej zatrudnionych było pięciu pracowników pełnoetatowych: Józef Karpinowicz (redaktor odpowiedzialny), Dorota Żelazo (sekretarz odpowiedzialny), Iser Serlin (redaktor), Maria Szwarcman (tłumacz) i Lejzor Piekarz (tłumacz) $^{78}$.

Oprócz stałych pracowników istniał zespół współpracowników z całego kraju, którzy przysyłali lub dostarczali materiały, teksty literackie, artykuły, reportaże na różne tematy związane z życiem żydowskim w Polsce. Reprezentowali oni najważniejsze instytucje żydowskie w kraju, np.: TSKŻ, ŻIH, gazetę „Fołks-Sztyme”, wydawnictwo Idisz Buch. Do współpracowników redakcji ${ }^{79}$ należeli m.in.: Przewodniczący TSKŻ Grzegorz (Hersz) Smolar dostarczał materiały o życiu społecznym Żydów w Polsce i pisał felietony polemiczne pod pseudonimem Leon Mur; wiceprzewodniczący TSKŻ Dawid Sfard - zajmował się tematyką literacką i pisał notatki o literaturze i teatrze; wiceprzewodniczący TSKŻ Samuel Hurwicz - dostarczał notatki z działalności Towarzystwa. Sekretarz TSKŻ Julian Łazebnik był odpowiedzialny za całokształt zagadnień związanych ze społeczno-kulturalną działalnością Żydów w Polsce; dyrektor ŻIH-u Bernard Mark informował o sprawach Instytutu i trudnił się krytyką literacką; poeta Binem Heller pisał felietony literackie i zajmował się tematem twórczości literackiej w Polsce; poeta Lejb Olicki i pisarz Icchok Guterman dostarczali również teksty literackie, felietony i opowiadania; Szymon Kanc był korespondentem terenowym i przysyłał reportaże gospodarcze i kulturalne z życia Żydów na Dolnym Śląsku; współpracownik „Fołks-Sztyme”, Ignacy Samsonowicz, zajmował się tematyką gospodarczą; redaktor działu „Fołks-Sztyme”, Salomon Łastik - tematyką kulturalną i krytyką literacką; dyrektor wydawnictwa Idisz Buch, Jakub Egit, pisał o zagadnieniach wydawniczych. Zespół Państwowego Teatru Żydowskiego nagrał wiele słuchowisk teatralnych ${ }^{80}$.

${ }^{76}$ Por. np. Protokół nr 46 posiedzenia Prezydium z dnia 19 czerwca 1954 r., Archiwum TSKŻ w Warszawie, brak sygn.

77 Dokumentacja zebrana w zbiorach własnych autorki.

${ }^{78}$ Na podstawie dokumentu w języku polskim: Wykaz pracowników redakcji żydowskiej. Brakuje dokładnej daty - prawdopodobnie rok 1952. Zbiory własne autorki.

${ }^{79}$ Podział pracy w dostarczaniu materiałów dla audycji żydowskich ustalony na konferencji TSKŻ z redaktorem Józefem Karpinowiczem 3 stycznia 1951 r. Dokument w języku polskim, zbiory własne autorki.

${ }^{80}$ Świadczą o tym zachowane nagrania słuchowisk z wymienionymi nazwiskami wykonawców znajdujące się w Archiwum Polskiego Radia, Narodowym Archiwum Cyfrowym, 
Redakcję zasilała zatem cała plejada najwybitniejszych twórców kultury i działaczy społecznych ówczesnej żydowskiej Polski ${ }^{81}$.

Pod koniec 1950 r. piętnastominutową audycję w jidysz nadawano codziennie o godz. 19.45 na falach krótkich 48,23 m, a tygodniowy program był następujący:

Poniedziałek: Przegląd wydarzeń międzynarodowych.

Wtorek: Reportaże i przeglądy kulturalne z życia żydowskiego w kraju.

Środa: Problematyka Izraela i udział mas żydowskich w walce o pokój.

Czwartek: Reportaże z życia żydowskiego, rozmowy z przodownikami pracy i odznaczonymi robotnikami żydowskimi.

Piątek: Audycje poświęcone literaturze żydowskiej w Polsce i za granicą.

Sobota: Felietony społeczno-bytowe.

Niedziela: Audycje muzyczne ${ }^{82}$.

Czasem audycje były dłuższe, na przykład z okazji rocznicy powstania w getcie warszawskim (19 kwietnia). Dłuższe także bywały audycje specjalne, poświęcone twórczości klasyków literatury jidysz: Icchokowi

YIVO Archives oraz w zbiorach prywatnych. Wśród artystów Państwowego Teatru Żydowskiego, którzy nagrywali słuchowiska dla audycji żydowskich np. w 1953 r., wymienieni są: Ida Kamińska, Mejer Melman, Izak Turkow, Michał Szwejlich, Józef Widecki, Rut Kowalska, Rachela Szpan, Marek Warszawski, Ketty Bujnowska, Szura Grinhaus, Genowefa Sztraser, Maria Wytysińska, Włodzimierz Rojtenteller. Dokument z 7 września 1953 r., list z redakcji żydowskiej do wiceprezesa Komitetu ds. Radiofonii „Polskie Radio”, podpisany przez redaktora odpowiedzialnego Józefa Karpinowicza i sekretarz redakcji Dorotę Żelazo. Zbiory własne autorki.

${ }^{81}$ Wydawana w Kanadzie gazeta codzienna „Wochenblat” informowała: „Oprócz stałych współpracowników w audycjach radiowych biorą udział najpoważniejsze siły z kraju, a od czasu do czasu goście z zagranicy. W radio często występują znani działacze społeczno-kulturalni: G[rzegorz] Smolar, J[ulian] Łazebnik, B[ernard] Mark; pisarze i poeci: Heller, Olicki, Lastik; reżyserowie teatru: Kamińska, Rotbaum; żydowscy muzycy i śpiewacy: Rohatyner, Zajnfeld, Łaska; wiolonczelistka Kowalska, skrzypek Poleski, Lednicki, pianistka Fajnsztajn. Występują także żydowscy mówcy, wyrastający i rozwijający się we wszystkich żydowskich skupiskach. Dzieci przez radio opowiadają o szkole żydowskiej”. Przekład artykułu wydrukowanego w „Wochenblat” (28 grudnia 1950), zbiory własne autorki. Więcej informacji na temat wielu z tych postaci czytelnik znajdzie m.in. w takich współczesnych opracowaniach, jak: August Grabski, Grzegorz Berendt, Między emigracją a trwaniem. Syjoniści $i$ komuniści żydowscy w Polsce po Holocauście, Warszawa 2003; Joanna Nalewajko-Kulikov, Obywatel Jidyszlandu. Rzecz o żydowskich komunistach w Polsce, Warszawa 2009; Magdalena Ruta, Bez Żydów? Literatura jidysz w powojennej PRL o Zagładzie, Polsce i komunizmie, Kraków 2012; Nie nad rzekami Babilonu. Antologia poezji jidysz w powojennej Polsce, thum., red. oraz słowo wstępne Magdalena Ruta, Kraków 2012.

${ }^{82} \mathrm{Na}$ podstawie następującego artykułu z paryskiej codziennej gazety ludowej: Henri Garber, Di jidisze sztime ojf di eter-chwaljes, „Naje Prese” (6 grudnia 1950), oraz dokumentów redakcji żydowskiej w zbiorach własnych autorki. 
Lejbuszowi Perecowi, Mendelemu Mojcherowi Sforimowi, Szolemowi Alejchemowi.

W 1951 r. doszło do następnej zmiany - zaczęto nadawać dwie audycje dziennie i rozszerzono czas ich trwania do 27 i pół minuty każda. Jedna audycja była przeznaczona dla krajów europejskich oraz Izraela (o godz. 22.50 czasu środkowoeuropejskiego na falach krótkich 48,23 m), druga zaś dla Żydów mieszkających w Ameryce (o godz. 5.45 czasu środkowoeuropejskiego na falach krótkich 41,64 m). Każda rozpoczynała się zapowiedzią i sygnałem radiowym opartym na melodii słynnego hymnu partyzanckiego Hersza Glika Zog nicht kejnmol [Nigdy nie mów] ${ }^{83}$.

Zapowiedź w audycji dla Europy i Izraela brzmiała: „Do redt Warsze. Gutn ownt libe cuherer. Mir hejbn on undzer tegleche ojdicje in der jidiszer szprach. Hert di sztim fun emes, fun frajntszaft, fun szolem" "84. Audycja dla Ameryki rozpoczynała się podobnie: „Do redt Warsze. Gutn ownt libe cuherer. Mir hejbn on undzer teglechn radjo-program in der jidiszer szprach far di jidn in Amerike. Hert di sztim fun emes, fun frajntszaft, fun szolem" Po tych słowach przywitania następował sygnał radiowy, a potem dalsza część zapowiedzi z podaniem częstotliwości fali dla słuchania audycji ${ }^{86}$. Już w zapowiedziach audycji widzimy elementy języka propagandy politycznej: „Słuchajcie głosu prawdy, przyjaźni, pokoju”. Język audycji żydowskich z lat pięćdziesiątych był nasycony takimi ściśle ustalonymi formułami i zwrotami, typowymi dla języka propagandy tego okresu ${ }^{87}$.

Audycje w języku jidysz cieszyły się dużym powodzeniem - słuchacze z całego świata przysyłali listy, wyrazy uznania i podziękowania. Podkreślali walory kulturalne i językowe audycji, ze wzruszeniem opisywali, jakie znaczenie mają dla nich audycje w języku jidysz nadawane $\mathrm{z}$ Warszawy, z jakim

${ }^{83}$ Nagranie sygnału i zapowiedzi audycji w języku jidysz z lat pięćdziesiątych. Zbiory własne autorki.

84 „Tu mówi Warszawa. Dobry wieczór, drodzy słuchacze. Rozpoczynamy naszą codzienną audycję w języku żydowskim. Słuchajcie głosu prawdy, przyjaźni, pokoju”. Nagranie sygnału i zapowiedzi audycji w języku jidysz z lat pięćdziesiątych. Zbiory własne autorki.

${ }^{85}$ „Tu mówi Warszawa. Dobry wieczór, drodzy słuchacze. Rozpoczynamy nasz codzienny program radiowy w języku żydowskim dla Żydów w Ameryce. Słuchajcie głosu prawdy, przyjaźni, pokoju”. Nagranie sygnału i zapowiedzi audycji w języku jidysz z lat pięćdziesiątych. Zbiory własne autorki.

${ }^{86}$ Nagranie sygnału i zapowiedzi audycji w języku jidysz z lat pięćdziesiątych. Zbiory własne autorki.

${ }^{87} \mathrm{Na}$ temat języka propagandy ukazało się wiele publikacji. Zjawiska w języku polskiej propagandy opisują np.: Małgorzata Zalewska, Język polskiej propagandy prasowej lat pięćdziesiatych, „Acta Univesitatis Lodziensis. Folia Sociologica” 20 (1990), s. 179-201; Michał Głowiński, Nowomowa po polsku, Warszawa 1991; Marcin Czyżniewski, Propaganda polityczna władzy ludowej w Polsce 1944-1956, Toruń 2005. 
zaciekawieniem słuchają bieżących informacji na temat życia żydowskiego w Polsce i jaką radość sprawiają im pieśni, słuchowiska, prezentacje utworów literackich w języku żydowskim ${ }^{88}$. Do redakcji przysyłano prasę żydowską z całego świata, natomiast z Warszawy wysyłano np. „Ojfgang”" a także taśmy z wybranymi nagraniami do Rumunii (w Bukareszcie także emitowano audycję żydowską), do Australii i Nowego Jorku ${ }^{90}$.

W latach pięćdziesiątych, zwłaszcza w ich II połowie, coraz wyraźniej dawała o sobie znać rozbieżność między pierwotnymi, wywodzącymi się z koncepcji Turkowa, założeniami audycji radiowych w języku żydowskim (poszukiwanie zaginionych, przekazywanie informacji o prawdziwej sytuacji Żydów w Polsce) a zadaniami stawianymi przez władze polskie przed redakcjami Programu Zagranicznego Polskiego Radia. Zadania te zostały bardzo szczegółowo wyartykułowane w notatce Edwarda Uzdańskiego ${ }^{91}$ w sprawie zagranicznych audycji Polskiego Radia, przygotowanej na potrzeby Biura Politycznego PZPR ${ }^{92}$. Do uchwały Biura Politycznego PZPR włączono zasadnicze zdanie: „W systemie propagandy polskiej za granica audycje obcojęzyczne Polskiego Radia spełniają rolę szczególnie ważną"93. W rozwinięciu założeń programowych ustalono szczegółowe warunki:

Zespół Programu Zagranicznego winien w swoich audycjach: 1) Nieustannie propagować zasady pokojowego współistnienia państw o różnych systemach ustroju społecznego i politycznego oraz pokojowej ich rywalizacji [...], 2) Popularyzować pokojową politykę Polski Ludowej; pokazywać jej rolę w walce o pokój, osiągnięcia pokojowej, twórczej pracy narodu polskiego, rozwój politycznych, dyplomatycznych, gospodarczych, kulturalnych stosunków i więzi Polski z innymi państwami, 3) Popularyzować politykę pokoju ZSRR i krajów demokracji ludowej, pokazywać osiągnięcia obozu pokoju, 4) Popularyzować akcje Światowej Rady Pokoju

${ }^{88}$ Zachowane listy słuchaczy do redakcji żydowskiej z lat 1950-1958. Zbiory własne autorki.

89 „Ojfgang” - miesięcznik młodzieżowy wydawany od 1947 r. przez CKŻP, a następnie przez Wydział Młodzieżowy TSKŻ.

${ }^{90}$ Korespondencja i dokumentacja ze zbiorów własnych autorki.

${ }^{91}$ Edward Uzdański był działaczem pionu propagandy PZPR, a w latach 1953-1955 pełnił funkcję zastępcy przewodniczącego Zespołu Programów dla Zagranicy w Polskim Radio. „Biuletyn Informacji Publicznej IPN”, Katalog kierowniczych stanowisk partyjnych i państwowych PRL, https://katalog.bip.ipn.gov.pl/informacje/40687 [dostęp: 1 stycznia 2017].

${ }^{92}$ Edward Uzdański, Notatka ws. zagranicznych audycji Polskiego Radia, maszynopis (23 strony), Warszawa, 14 czerwca 1955 r., Cyfrowa Biblioteka Narodowa Polona; dokument pochodzący z Archiwum Dokumentacji Mechanicznej (k. 239-262), https://polona. $\mathrm{pl} /$ item/notatka-w-sprawie-zagranicznych-audycji-polskiego-radia,MTA4NzU2NzM/0/\#info:metadata [dostęp: 1 stycznia 2017].

93 Tamże, s. 1. 
i ruchu obrońców pokoju [...], 5) Informować szybko i dokładnie o wydarzeniach międzynarodowych, zwłaszcza o walce klasy robotniczej i mas pracujących krajów kapitalistycznych [...], 6) Walczyć o systematyczną poprawę treści i formy audycji, o maksymalne przybliżenie ich do audytorium każdego kraju, o systematyczną poprawę materiałów propagandowych o tematyce polskiej, o zwiększenie liczby audycji o wysokich walorach artystycznych i literackich, do systematycznej poprawy kompozycji audycji i ich oprawy artystycznej, do dalszego doskonalenia realizacji, wzmocnić kierownictwo, dbać o zasilenie kadr programowych wysokich kwalifikacji dziennikarzami, speakerami, lektorami, tłumaczami, redaktorami literackimi i muzycznymi, reżyserami i inżynierami ${ }^{94}$.

Nadawane przez 55 minut na dobę audycje w języku żydowskim były realizowane przez jedną z osiemnastu redakcji tematycznych. Z pewnością również jej dotyczyły nie tylko powyższe postulaty, ale także pozytywne oceny i krytyczne uwagi sformułowane w notatce Uzdańskiego. Wśród ocen pozytywnych podkreślono, że „spokój, umiar, rzeczowość, stosunkowa lekkość formy cechujące nasze audycje zdobyły dla nich uznanie" ${ }^{\prime 5}$ oraz że z audycji tych korzysta się jako ze źródła informacji. Uwagi krytyczne dotyczyły m.in. zdezorientowania w wybranych kwestiach merytorycznych, jakościowych i ilościowych braków kadrowych, niedociągnięć organizacyjno-koordynacyjnych oraz słabego wyposażenia technicznego, skutkującego niedostateczną słyszalnością programów za granicą ${ }^{96}$. W notatce sformułowano dramatyczny apel do władz polityczno-państwowych o uzupełnienie braków kadrowych i technicznych, w tym zwłaszcza o modernizację infrastruktury i wyposażenie w nowe nadajniki dużej mocy, jako warunek dalszego funkcjonowania programów radia dla zagranicy. W kontekście takiej oceny i apelu można przypuszczać, że ograniczenia finansowe stały się jednym z formalnych argumentów późniejszej decyzji o likwidacji niektórych językowych redakcji radiowych.

\section{Zakończenie nadawania audycji w roku 1958}

Audycje w języku jidysz były nadawane do roku 1958. Działalność redakcji tych audycji została zakończona w następstwie decyzji Sekretariatu KC PZPR z 15 stycznia 1958 r. To samo zresztą stało się w kolejnych miesiącach z kilkoma innymi redakcjami zagranicznymi Polskiego Radia. W lutym

\footnotetext{
94 Tamże, s. 11-12.

95 Tamże, s. 1.

96 Tamże, s. 1 i n.
} 
i marcu zlikwidowano redakcje: rosyjską, żydowską, turecką, grecką i jugosłowiańską, postanowiono natomiast wzmocnić audycje zachodnioeuropejskie i skandynawskie. Jednocześnie likwidacji uległa odrębna Redakcja Artystyczno-Muzyczna Programu Zagranicznego. Zmieniona została struktura Zespołu Programu dla Zagranicy. Powstały trzy piony: redakcja Audycji dla Polonii (w języku angielskim na Anglię, USA i kraje zamorskie), redakcja Audycji Obcojęzycznych (skandynawska, romańska i niemiecka) oraz usługowy Dział Centralny z redakcjami: Publicystyki i Informacji, Audycji Światowej Federacji Związków Zawodowych (ŚFZZ), Listów i Korespondentów, Kontroli Audycji. Ponadto w Naczelnej Redakcji Politycznej Programu Krajowego utworzono Redakcję Serwisu, która miała obsługiwać też Program dla Zagranicy. W uzasadnieniu powoływano się na uchwałę Sekretariatu KC PZPR ograniczającą liczbę etatów w programach zagranicznych. Ostatecznie zlikwidowano 130 etatów, pozostawiając 32997.

Ówczesny kierownik Biura Prasy KC PZPR Artur Starewicz, uzasadniając likwidację programu w jidysz, starał się zbagatelizować zastrzeżenia wskazujące na negatywny wydźwięk polityczny takiego kroku. Podkreślał utratę znaczenia audycji w języku jidysz. Uważał, że problem polityki narodowościowej może być naświetlany w innych językach: „Jeżeli chodzi o ludzi, którzy wyemigrowali z Polski, oni mogą doskonale słuchać programu polskiego. Jeśli chodzi o ludzi, którzy nie znają polskiego języka, a znają angielski, to mogą słuchać programu angielskiego"98.

Po zlikwidowaniu audycji słuchacze ze wszystkich zakątków świata przysyłali listy, ponieważ trudno im się było pogodzić z tą decyzją. Apelowali o jej przywrócenie ${ }^{99}$. Ukazały się też krytyczne artykuły i komentarze w prasie zagranicznej. Na przykład w paryskiej gazecie „Unzer Wort” (z 7 lutego 1958 r.) pojawił się artykuł Nie ma więcej, ,jidysz” w radio z Polski, a Żydowska Agencja Telegraficzna (JTA) poinformowała z Londynu, że Polskie Radio s. 56.

${ }^{97}$ Myśliński, Mikrofon i polityka..., s. 153-155; zob. także: Berendt, Życie żydowskie...,

98 Wypowiedź Artura Starewicza spisana przez Dorotę Żelazo w styczniu 1958 r. Dokument w zbiorach własnych autorki.

99 „Ja, razem z moimi przyjaciółmi, którzy byliśmy waszymi dumnymi i stałymi słuchaczami audycji w języku żydowskim, tych audycji, które wysyłaliście w eter, audycji z wiadomościami i literackimi felietonami o wysokiej jakości, z których mieliśmy tyle zadowolenia! Drodzy przyjaciele! Jak można popełnić taką krzywdę? Ja mogę być śwadkiem oraz wielu innych, że mieliście dużo słuchaczy u nas w Kopenhadze i w całej Europie. [...] Apeluję do Was, przyjaciele, nie przemilczcie tej krzywdy i niech krzywda ta zostanie naprawiona. [...] Mam nadzieję, że wznowicie wasze audycje, które były tak lubiane!" Cytat z listu słuchacza z Kopenhagi, Salomona Asinoffskiego, z 18 lutego 1958 r. Zbiory własne autorki. 
podało wiadomość o zaprzestaniu nadawania audycji w jidysz, słuchaczom żydowskim zaś rekomenduje się audycje tego radia w innych językach ${ }^{100}$.

Decyzji zamknięcia audycji sprzeciwiały się środowiska żydowskie. TSKŻ dało wyraz swojemu oburzeniu z powodu przyjęcia uchwały o likwidacji bez konsultowania się z przedstawicielami społeczeństwa żydowskiego, uznając tę decyzję za wysoce krzywdzącą dla wielu tysięcy przeważnie pochodzących z Polski słuchaczy żydowskich, dla których ta audycja była jedynym źródłem informacji o Polsce Ludowej. W piśmie, podpisanym przez przewodniczącego TSKŻ Grzegorza Smolara oraz sekretarza TSKŻ Dawida Sfarda, skierowanym do Artura Starewicza z Biura Prasowego KC PZPR, wyraźnie podkreślono, że uchwała ta może być rozumiana jako wyraz tendencji do likwidacji wszystkiego, co łączy się z kulturą i językiem żydowskim ${ }^{101}$.

\section{Epilog}

Co było dalej? Po pięćdziesięciu latach, w 2008 r., znowu w Polsce zabrzmiał przez radio język jidysz. W ramach Redakcji Hebrajskiej Kol Polin Polskiego Radia dla Zagranicy utworzono audycję Naje Chwaljes (Nowe Fale). Początkowo nadawano ją przez piętnaście minut co dwa tygodnie, w niedzielę, ale ponieważ programy cieszyły się dużym powodzeniem, podwojono ich liczbę - emitowano je co tydzień i wydłużono czas antenowy do pół godziny. Przedstawiano w nich wywiady i reportaże informujące o życiu żydowskim i wydarzeniach kulturalnych w Polsce i na świecie, prezentowano nową muzyką żydowską i utwory w języku jidysz oraz specjalny program dla dzieci Kinder-winkl. Programów słuchano zarówno w Polsce, jak i na całym świecie - oprócz osób ze starszego pokolenia, które wyniosły jidysz z domu, wśród odbiorców znaleźli się także przedstawiciele młodej generacji, studenci, osoby zainteresowane jidysz i uczące się tego języka.

Audycja Naje Chwaljes została zamknięta z początkiem stycznia 2012 r. na skutek reorganizacji Redakcji Hebrajskiej, która zmierzała do nadawania tylko po hebrajsku i po angielsku. Jako dodatkową przyczynę podano konieczność optymalizacji wykorzystania posiadanych środków

${ }^{100}$ Notatka z wychodzącej w Paryżu gazety żydowskiej „Unzer Wort” (7 lutego 1958). Dokument w języku polskim, zbiory własne autorki.

${ }^{101}$ List do Biura Prasowego KC PZPR na ręce tow. Starewicza z 10 stycznia 1958 r., podpisany przez G[rzegorza] Smolara i D[awida] Sfarda. Dokument w zbiorach własnych autorki. 
finansowych. Podobnie jak w 1958 r. na zniknięcie audycji w języku jidysz zareagowali słuchacze:

Jestem zdumiony wiadomością, że Dyrekcja Polskiego Radia postanowiła zlikwidować program Naje Chwaljes („Nowe Fale”) w sekcji żydowskiej Polskiego Radia. Uważam, że będzie to ogromna strata dla Polskiego Radia dla Zagranicy, gdyż audycja Naje Chwaljes reprezentuje wysoki poziom kulturalny i społeczny.

Dla mnie osobiście to szczególnie bolesny cios. Cios dla więzi z moim ojczystym krajem, w którym się urodziłem (w Warszawie) i wychowałem, w którym pozostawiłem całą moją wymordowaną rodzinę i wszystkie wspomnienia moich lat młodzieńczych.

Opuściłem Polskę w listopadzie 1948 roku i język jidysz, mój język ojczysty, który słyszę przez radio z Polski, pozwala mi utrzymać tę intymną więź z moją przeszłością i moją polską ojczyzną ${ }^{102}$.

\section{Bibliografia}

\section{1. Źródła archiwalne}

Archiwum TSKŻ w Warszawie, Protokół nr 46 posiedzenia Prezydium z dnia 19 czerwca 1954 r., brak sygn.

Archiwum Żydowskiego Instytutu Historycznego

Spuścizna Jonasa Turkowa, sygn. S/364/1a, S/364/4a.

Wydział Kultury i Propagandy, sygn. 303/XIII/68, 303/XIII/69, 303/XIII/70, 303/

XIII/71, 303/XIII/72, 303/XIII/73, 303/XIII/74, 303/XIII/75, 303/XIII/76, 303/

XIII/79, 303/XIII/89, 303/XIII/96, 303/XIII/98, 303/XIII/106, 303/XIII/112, 303/XIII/129.

Ghetto Fighters' House Archives

Anszel Reiss Collection, sygn. 28131.

Jonas Turkow Collection, sygn. 21414.

YIVO Archives, Territorial Collection, Poland III, sygn. RG116-Poland 3, folder 6;

RG116-Poland 3, folder 18; RG116-Poland 3, folder 186.

Dokumenty w zbiorach własnych autorki:

List do Biura Prasowego KC PZPR na ręce tow. Starewicza z 10 stycznia 1958 r., podpisany przez G[rzegorza] Smolara i D[awida] Sfarda.

List Icchoka Ludena do Dyrekcji Polskiego Radia z 16 grudnia 2011 r.

List słuchacza z Kopenhagi, Salomona Asinoffskiego, z 18 lutego 1958 r.

List z redakcji żydowskiej do wiceprezesa Komitetu ds. Radiofonii „Polskie Radio”

z 7 września 1953 r., podpisany przez redaktora odpowiedzialnego Józefa

Karpinowicza i sekretarz redakcji Dorotę Żelazo.

Listy słuchaczy do redakcji żydowskiej z lat 1950-1958.

102 Cytat pochodzi z listu Icchoka Ludena (1922-2017), dziennikarza, wieloletniego działacza bundowskiego, redaktora wychodzącej w Izraelu gazety „Lebens-fragen”. List do Dyrekcji Polskiego Radia z 16 grudnia 2011 r. Ze zbiorów własnych autorki. 
Nagranie sygnału i zapowiedzi audycji w języku jidysz z lat pięćdziesiątych.

Notatka z wychodzącej w Paryżu gazety żydowskiej „Unzer Wort” z 7 lutego 1958. Podział pracy w dostarczaniu materiałów dla audycji żydowskich ustalony na

konferencji TSKŻ z redaktorem Józefem Karpinowiczem 3 stycznia 1951 r. Przekład artykułu wydrukowanego w „Wochenblat” (28 grudnia 1950).

Wykaz pracowników redakcji żydowskiej, b.d. (prawdopodobnie 1952).

Wypowiedź Artura Starewicza, spisana przez Dorotę Żelazo w styczniu 1958 r.

\section{2. Źródła opublikowane}

„Biuletyn Informacji Publicznej IPN”, Katalog kierowniczych stanowisk partyjnych i państwowych PRL, https://katalog.bip.ipn.gov.pl/informacje/40687 [dostęp: 1 stycznia 2017].

„Biuletyn Wydziału Młodzieżowego Centralnego Komitetu Żydów Polskich” (1947), nr 4-5.

„Biuletyn Żydowskiej Agencji Prasowej” (13 listopada 1944), nr 1.

Blumental Nachman, Lublin noch der cwejter welt-milchome, [w:] Dos Buch fun Lublin, Paris 1952.

Dzieje Żydów w Polsce, 1944-1968. Teksty źródłowe, oprac. Alina Cała, Helena Datner-Śpiewak, Warszawa 1997.

Ehrenreich Chaim, Di ejncike cwej aktjorn wos hobn zich geratewet fun der warszewer geto, „Forwerts” 54 (12 listopada 1950).

Garber Henri, Di jidisze sztime ojf di eter-chwaljes, „Naje Prese” (6 grudnia 1950). Jewish Telegraphic Agency, http://www.jta.org/1944/12/10/archive/jews-flee-from-nazi-held-poland-to-liberated-area-communal-life-in-lublin-revives [dostęp: 1 stycznia 2017].

Kiernik Władystaw (1879-1971), https://bs.sejm.gov.pl/F?func=find-b\&request $=000000642 \&$ find_code $=$ SYS\&local_base $=$ ARS10 [dostęp: 1 stycznia 2017].

Manifest PKWN, Dziennik Ustaw z 1944 r., nr 1.

Nie nad rzekami Babilonu. Antologia poezji jidysz w powojennej Polsce, tłum., red. oraz słowo wstępne Magdalena Ruta, Kraków 2012.

Powojenne Polskie Radio $i$ jego szef, wywiad z Wilhelmem Billigem z 8 lipca 1979 r. w audycji radiowej, http://www.polskieradio.pl/9/310/ Artykul/276241,Powojenne-Polskie-Radio-i-jego-szef [dostęp: 1 stycznia 2017]. „Trotz alledem lebe ich”. Jüdisches Leben in den DP-Lager 1945-1956, http://www. yadvashem.org/yv/de/exhibitions/dp_camps/index.asp [dostęp: 1 stycznia 2017].

Turkow Jonas, In kamf farn lebn, Buenos Aires 1949.

Turkow Jonas, Noch der bafrajung: zichrojnes, Buenos Aires 1959.

Uzdański Edward, Notatka ws. zagranicznych audycji Polskiego Radia, maszynopis (23 strony), Warszawa, 14 czerwca 1955 r., Cyfrowa Biblioteka Narodowa Polona; dokument pochodzący z Archiwum Dokumentacji Mechanicznej, https://katalog.bip.ipn.gov.pl/informacje/40687 [dostęp: 1 stycznia 2017].

Yoysef Okrutni (Iosef Okrutny), http://yleksikon.blogspot.de/2014/09/yoysef-okrutni-iosef-okrutny.html [dostęp: 1 stycznia 2017]. 
Zarys działalności Centralnego Komitetu Żydów w Polsce za okres od 1 stycznia do 30 czerwca 1946, Warszawa 1947 / Tetikajts-baricht fun Central-komitet fun di Jidn in Pojln fun 1 januar 1946 biz dem 30 juni 1946, Warsze 1946.

\section{Opracowania}

Aleksiun Natalia, Żydowska Agencja Telegraficzna ( $\dot{Z} A T)$, [w:] Polski słownik judaistyczny, http://www.jhi.pl/psj/Zydowska_Agencja_Telegraficzna_(ZAT) [dostęp: 1 stycznia 2017].

Berendt Grzegorz, Życie żydowskie w Polsce w latach 1950-1956. Z dziejów Towarzystwa Społeczno-Kulturalnego Żydów w Polsce, Gdańsk 2008.

Cała Alina, Mniejszość żydowska, [w:] Mniejszości narodowe w Polsce, red. Piotr Madajczyk, Warszawa 1998.

Cała Alina, Węgrzynek Hanna, Zalewska Gabriela, Historia i kultura Żydów polskich. Stownik, Warszawa 2000.

Chmielewska Lucyna, Wincenty Rzymowski (1883-1950). Publicysta i polityk, „Dzieje Najnowsze" 36 (2004), nr 2.

Cohen Nathan, The Renewed Association of Yiddish Writers and Journalists in Poland, 1945-48, [w:] Yiddish after the Holocaust, red. Joseph Sherman, Oxford 2004.

Czyżniewski Marcin, Propaganda polityczna władzy ludowej w Polsce 1944-1956, Toruń 2005.

Fornal Stanisław, Anteny nad Bystrzyca, Lublin 1997.

Głowiński Michał, Nowomowa po polsku, Warszawa 1991.

Grabski August, Centralny Komitet Żydów w Polsce (1944-1950). Historia polityczna, Warszawa 2015.

Grabski August, Berendt Grzegorz, Między emigracją a trwaniem. Syjoniści i komuniści żydowscy w Polsce po Holocauście, Warszawa 2003.

Hass Ludwik, Rzymowski Wincenty, [w:] Polski Stownik Biograficzny, t. 34/2, z. 141, Wrocław 1992.

Kalicki Wojciech, Aparat propagandowy PPR (1944-1948), „Z Pola Walki” (1987), nr 1.

Myśliński Jerzy, Kadra kierownicza Polskiego Radia w latach 1944-1960, „Kwartalnik Historii Prasy Polskiej” 30 (1991), nr 1.

Myśliński Jerzy, Mikrofon i polityka. Z dziejów radiofonii polskiej 1944-1960, Warszawa 1990.

Myśliński Jerzy, Radiofonia polska w latach 1944-1949, „Kwartalnik Historii Prasy Polskiej” 28 (1989), nr 3.

Nalewajko-Kulikov Joanna, Obywatel Jidyszlandu. Rzecz o żydowskich komunistach w Polsce, Warszawa 2009.

Następstwa zagłady Żydów. Polska 1944-2010, red. Feliks Tych, Monika Adamczyk-Garbowska, Lublin 2011.

Rudnicki Szymon, Żydzi w parlamencie II Rzeczypospolitej, Warszawa 2004.

Ruta Magdalena, Bez Żydów? Literatura jidysz w powojennej PRL o Zagładzie, Polsce i komunizmie, Kraków 2012. 
Sobór-Świderska Anna, Jakub Berman. Biografia komunisty, Warszawa 2009.

Tłomacki Andrzej, Powrót do Polski w latach 1945-1948 pótnocnych rejonów Spiszu. Przyczynek do dziejów sporów granicznych między Polakami, Czechami i Słowakami, „Bezpieczeństwo. Teoria i Praktyka” (2011), nr 1.

Zalewska Małgorzata, Język polskiej propagandy prasowej lat pięćdziesiątych, „Acta Univesitatis Lodziensis. Folia Sociologica” 20 (1990).

Anna Rozenfeld Uniwersytet Warszawski Selma Stern Zentrum für Jüdische Studien Berlin-Brandenburg rozenfeldan@gmail.com 